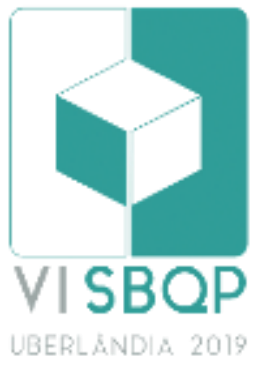

\title{
ENSAIO PROJETUAL PARA A MOBILIDADE ATIVA: EXPLORANDO A CAMINHABILIDADE NA AV. DR. JAIR DE ANDRADE
}

\author{
ZON, Mateus Marcarini \\ Universidade Vila Velha (UVV), e-mail: zon.arquitetura@gmail.com \\ RAMOS, Larissa Leticia Andara \\ Universidade Vila Velha (UVV), e-mail: larissa.ramos@uvv.br
}

\begin{abstract}
RESUMO
As cidades contemporâneas sofrem com o processo de adensamento que pressiona e ignora os espaços públicos da cidade. A ênfase no uso de veículos individuais resulta em espaços cada vez menores para o pedestre, prejudicado a vivência urbana e a caminhabllidade nas cidades. A cidade de Vila Velha-ES é precária no que diz respeito a mobilidade ativa, com vias que, apesar do fluxo de pessoas, não valoriza o pedestre. A partir desse cenário, o presente trabalho apresenta um ensaio projetual para qualidade dos espaços públicos, em especial para a melhoria nos deslocamentos a pé, tendo como recorte a Av. Dr. Jair de Andrade. O desenvolvimento da proposta projetual investiga a aplicação dos conceitos de vitalidade urbana, caminhabilidade e valorização do pedestre, embasado nas teorias de Jacobs (2000), Gehl (2013) e Speck (2016). A pesquisa ainda elucida as técnicas de análise: levantamento fotográfico, contagem de fluxo, questionários, observação comportamental, diário de campo e caminhada teste. A proposta baseou-se na valorização e proteção do pedestre, no aumento da qualidade socioambiental da via, no estimulo a fachadas ativas e no resgate da ciclovia, de modo melhorar a qualidade do espaço urbano de vias urbanas.
\end{abstract}

Palavras-chave: Caminhabilidade, Pedestres, Mobilidade ativa, Calçadas, deslocamento à pe.

\begin{abstract}
The Contemporary cities suffer with the process of densification that presses and ignores the public spaces of the city. The emphasis on the use of individual vehicles results in smaller spaces for the pedestrian, hampering urban living and walking in cities. The city of Vila Velha-ES is precarious in terms of active mobility, with routes that, despite the flow of people, do not value the pedestrian. From this scenario, the present work presents a design essay for the quality of the public spaces, in particular for the improvement in the displacements on foot, having as a cut Av. Dr. Jair de Andrade. The development of the project proposal investigates the application of the concepts of urban vitality, walkability and pedestrian valorization, based on the theories of Jacobs (2000), Gehl (2013) and Speck (2016). The research still elucidates the techniques of analysis: photographic survey, flow count, questionnaires, behavioral observation, field diary and walk test. The proposal was based on the valorization and protection of the pedestrian, on increasing the social and environmental quality of the road, on stimulating active facades and on the rescue of the bicycle path, in order to improve the quality of urban space on urban roads.
\end{abstract}

Keywords: Walkability, Pedestrians, Active Mobility, Sidewalks, Walking Displacement.

\section{INTRODUÇÃO}

O modelo urbanístico baseado no uso do automóvel aumentou a segregação socioeconômica espacial, estimulando a incorporação de glebas com baixos níveis de integração às infraestruturas urbanas e estabelecendo um modelo de expansão periférica das cidades onde as desigualdades sociais, traço

ZON, M. M.; RAMOS, L. L. A. Ensaio Projetual para a Mobilidade Ativa: Explorando a Caminhabilidade na Av. Dr. Jair de Andrade. In: SIMPÓSIO BRASILEIRO DE QUALIDADE DO PROJETO NO AMBIENTE CONSTRUÍDO, 6., 2019, Uberlândia. Anais... Uberlândia: PPGAU/FAUED/UFU, 2019. p. 428-446. DOI https://doi.org/10.14393/sbqp19040. 
marcante da sociedade brasileira, foram cristalizadas na ocupação do solo urbano (GHIDINI, 2010).

Esse processo de ruptura, se retroalimenta porque a população é expulsa das áreas mais centrais da cidade, seja pelo alto custo da terra urbana e da moradia, seja pela degradação e baixa qualidade ambiental dos centros tradicionais. Dessa forma, a população passa a viver na periferia e a utilizar as áreas centrais como centros econômicos. Esse fator gera maior deslocamento da e, com isso, aumenta a necessidade de transporte para atender as necessidades diárias, que por sua vez, também colabora para a degradação ambiental e urbana. A cidade vai, assim, se desumanizando pela perda de vida e, consequentemente, a rua torna-se cada vez menos transitada, mais perigosa e sem acessibilidade (GHIDINI, 2010).

Os espaços públicos estão, cada vez mais, sofrendo com degradação, em muitos casos, causados pela circulação de modais de transporte individual, que por sua velocidade e consumo energético, além da polvição atmosférica e sonora, afugentam a vida social e coletiva. A rua, elemento estruturante e também social das cidades, vem sendo o ente urbano mais prejudicado dentro desta lógica. Sendo assim, recuperar a condição e a escala humana de bairros, praças e, sobretudo, das ruas, é necessário e urgente para a humanização do meio urbano (GHIDINI, 2010).

A cidade de Vila velha é precária no que diz respeito a mobilidade ativa, com vias que, apesar do fluxo constante de pessoas, é nítida a desvalorização do pedestre, em detrimento do uso do automóvel. Desse modo, o presente trabalho tem como objetivo apresentar uma reflexão sobre a caminhabilidade em bairros residências, através de um ensaio projetual para a melhoria nos deslocamentos a pé, tendo como recorte a Av. Dr. Jair de Andrade.

A pesquisa é de natureza aplicada e caráter exploratório e descritivo. O referencial teórico traz como principais autores: Jacobs (2000), Gehl (2013), Speck (2016), WRI (2017), Gehl e Svarre (2018). Para o diagnóstico da via objeto de estudo e posterior embasamento da proposta projetual foram ainda utilizadas as técnicas de levantamento fotográfico, contagem de fluxo de pedestre, questionários online, observação comportamental, diário de campo e caminhada teste.

\subsection{Caminhabilidade}

Segundo o urbanista Speck (2013), existem 3 (três) grandes argumentos que conduzem o pensamento para cidades mais caminháveis, que são do ponto de vista: econômico, saúde e ambiental.

A Caminhabilidade é uma medida quantitativa e qualitativa que analisa 0 quão convidativa ou não uma via pode ser para os pedestres. Dessa forma, leva em consideração a acessibilidade, a atratividade, o conforto e a segurança para mensurar a facilidade para as pessoas se deslocarem na cidade. Os índices de caminhabilidade influenciam diretamente na predisposição que as pessoas têm ou teriam para caminhar em determinados locais (SPECK, 2016).

Do ponto de vista conceitual, a caminhabilidade é uma qualidade do espaço público. O caminho que permite ao pedestre uma boa mobilidade às diferentes partes da cidade, garantido às crianças, aos idosos, às pessoas com 
dificuldades de locomoção e a todos. Assim, a caminhabilidade deve proporcionar uma motivação para induzir o pedestre a adotar o caminhar como forma de deslocamento, restabelecendo suas relações interdependentes com a cidade. E para tanto, deve comprometer recursos visando a reestruturação da infraestrutura física (passeios adequados e atrativos ao pedestre), tão necessárias à vida humana e à qualidade de vida urbana (GHIDINI, 2010).

Segundo Speck (2016), a caminhada deve ser proveitosa, segura, confortável e interessante. O autor ainda sugere um esquema composto por 10 (dez) passos que favorecem o desenvolvimento da caminhabilidade, conforme Figura 1, a seguir.

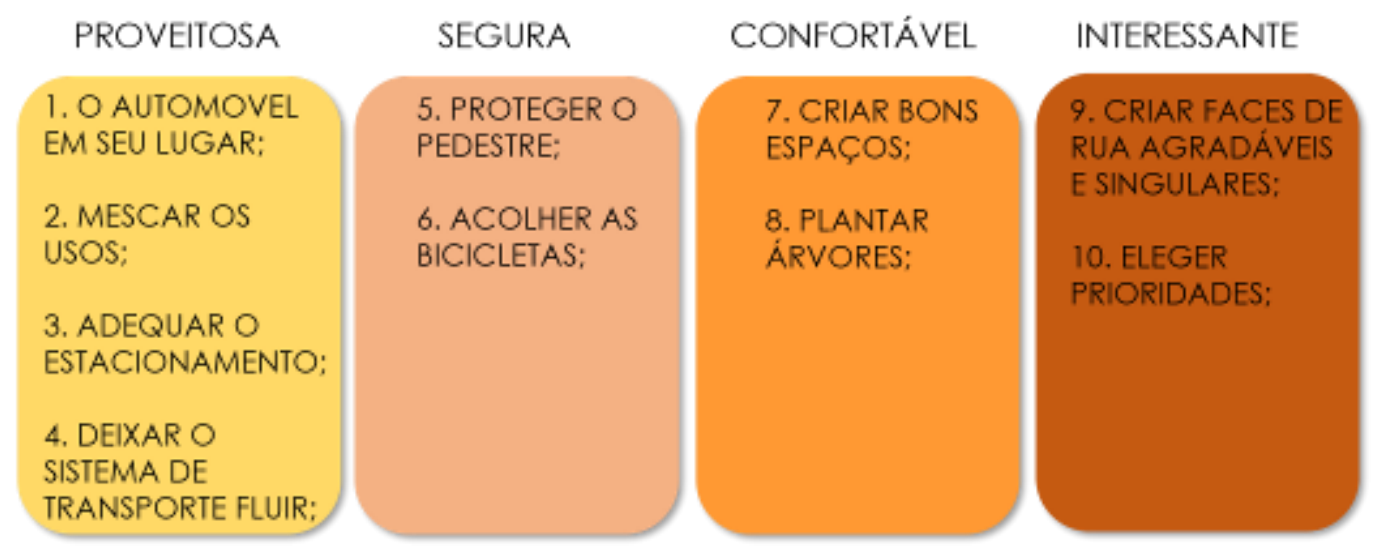

Figura 1 - Esquema dos 10 passos da caminhabilidade.

Fonte: elaborado pelos autores (2018), com base em Speck (2016).

\section{MATERIAL E MÉTODOS}

A Av. Dr. Jair de Andrade (identificada na Figura 2) é umas das vias de maior importância no município de Vila Velha-ES. Muitas atividades estão localizadas em torno dessa avenida, entretanto, observa-se - assim como acontece em outras vias do município - a falta de um desenho urbano que valorize pedestre e a mobilidade ativa, em especial os deslocamentos à pe.

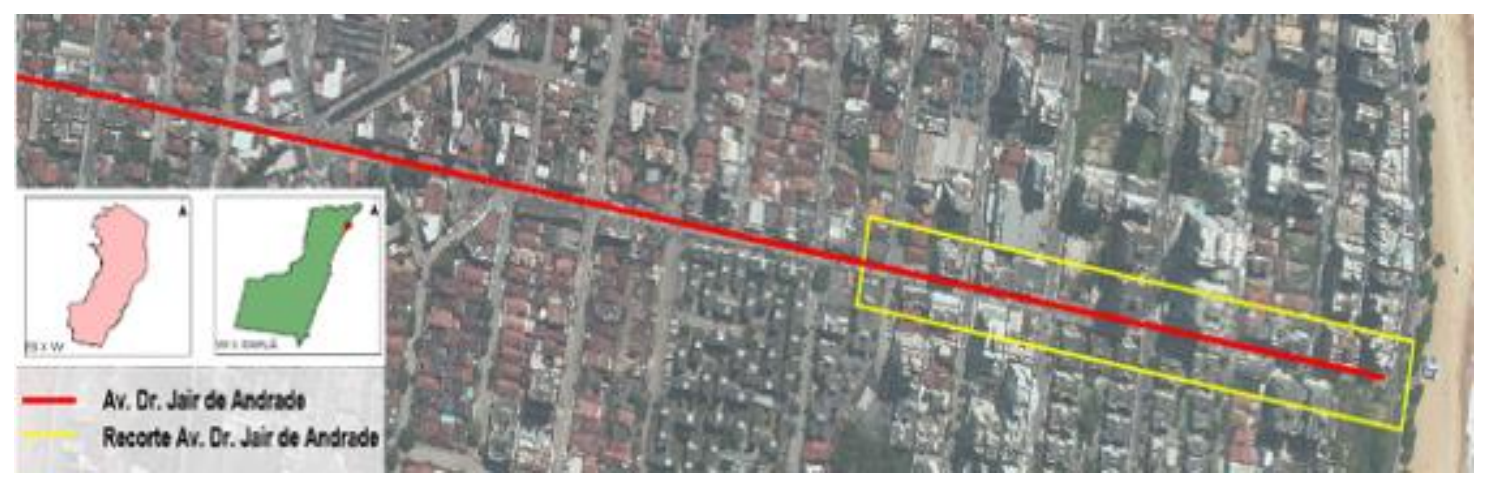

Figura 2 - Localização da Av. Jair de Andrade

Fonte: elaborado pelos autores (2018).

A escolha dessa via como objeto de estudo, parte de uma insatisfação pessoal na qual pode se observar a realidade de Vila Velha, a inquestionável desvalorização do pedestre.

Para compreender a visão do pedestre em relação caminhabilidade no município, foi desenvolvido um questionário online, disponibilizado nas redes sociais, no qual cerca de 200 usuários participaram, respondendo perguntas 
com sugestões e opiniões sobre o tema. Tais respostas contribuíram para indicar o nível de qualidade das calcadas, segundo a percepção dos munícipes

A partir das diferentes perguntas foi associado a cada classificação uma determinada nota seguindo a hierarquia: ÓTIMO, nota 5; BOM, nota 4; REGULAR, nota 3; RUIM, nota 2; e PÉSSIMO, nota 1. Com base nessa colocação foi relaizado um cálculo somando todas as respostas e criando uma média a fim de chegar a um coeficiente final, que é o índice de caminhabilidade do município de Vila Velha.

Foram contabilizadas 5 notas ótimas, 348 notas boas, 970 regulares, 868 ruins e 609 péssimas, somando um total de 2800 respostas, nas quais as quantidades de respostas representam uma porcentagem em relação ao valor total. A partir disso, chegou-se ao valor de 2,38 (índice de caminhabilidade) que está inferior a nota máxima (5). A seguir, estão o gráfico 1 e a nota que representam o quão caminháveis são as ruas e avenidas deste local.

ÍNDICE DE CAMINHABILIDADE

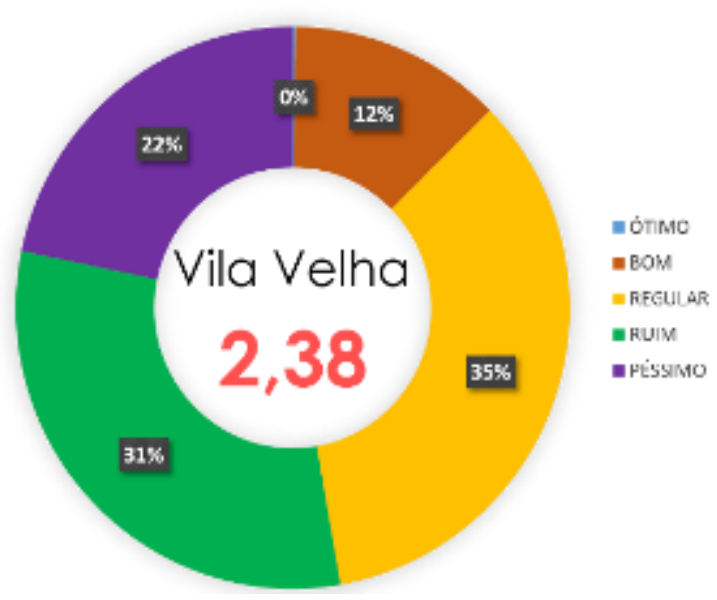

Gráfico 1 - índice de Caminhabilidade de Vila Velha.

Fonte: elaborado pelos autores (2018).

A contagem, baseada na metodologia do livro "A vida na cidade: como estudar" (GEHL; SVARRE; 2018)", foi realizada pela observação direta, visto que os usuários não estão ativamente envolvidos no sentido de serem questionados. Foram observados os pedestres em suas atividades e comportamentos, que foram mapeados para melhor compreender suas necessidades e como o espaço urbano é usado. Os dados ajudaram a entender o porquê de alguns espaços serem usados e outros não. Foram contados a circulação de pedestres das 7 horas da manhã às 22 horas da noite, em dias e horários alternados. A seguir, estão a figura 3, a tabela 1 e 0 gráfico 2 que demostram a metodologia e os resultados finais da contagem realizada. 


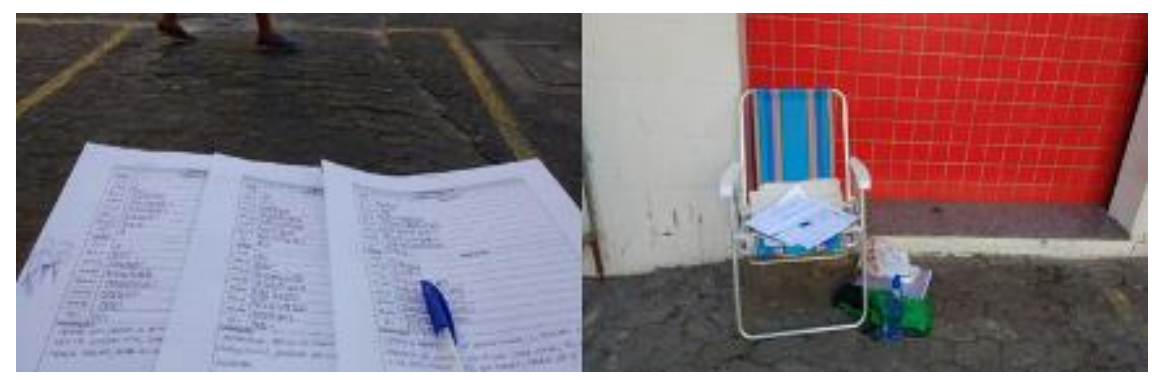

Figura 3 - Metodologia da contagem e espaço de utilização

Fonte: elaborado pelos autores (2018).

Tabela 1 - Contagem na Av. Dr. Jair de Andrade.

\begin{tabular}{|c|c|c|c|c|c|c|c|c|c|c|c|}
\hline \multicolumn{12}{|c|}{ CONT AGEM EM PONTO ESTRATÉGICO NA AV. DR. JAIR DE ANDRADE } \\
\hline \multirow{2}{*}{ GENÊRO } & \multirow{2}{*}{ HORÁRIO } & \multicolumn{8}{|c|}{ FAIXA ETÁRIA } & \multirow{2}{*}{\begin{tabular}{|c|} 
TOTAL GEN. \\
$\mathrm{N}^{\circ}$
\end{tabular}} & \multirow{2}{*}{$\frac{\text { TOTAL }}{\mathrm{N}^{\circ}}$} \\
\hline & & 0 à 09 & 10 à 19 & 20 à 29 & 30 à 39 & 40 à 49 & 50 à 59 & 60 à 69 & $70>$ & & \\
\hline FEMININO & \multirow{2}{*}{ 07:00 - 08:00 } & 3 & 10 & 29 & 33 & 33 & 28 & 16 & 5 & 157 & \multirow[b]{2}{*}{301} \\
\hline MASCULINO & & 4 & 12 & 22 & 30 & 32 & 23 & 13 & 8 & 144 & \\
\hline FEMININO & \multirow{2}{*}{-08:00-09:00 } & 7 & 9 & 25 & 36 & 36 & 27 & 33 & 7 & 180 & \multirow[b]{2}{*}{366} \\
\hline MASCULINO & & 7 & 12 & 32 & 35 & 29 & 34 & 24 & 13 & 186 & \\
\hline FEMININO & \multirow{2}{*}{$09: 00-10: 00$} & 17 & 13 & 34 & 45 & 39 & 39 & 46 & 18 & 251 & \multirow{2}{*}{511} \\
\hline MASCULINO & & 20 & 18 & 34 & 44 & 39 & 44 & 39 & 22 & 260 & \\
\hline FEMININO & \multirow{2}{*}{$10: 00-11: 00$} & 12 & 15 & 33 & 47 & 42 & 44 & 52 & 17 & 262 & \multirow{2}{*}{551} \\
\hline MASCULINO & & 19 & 20 & 38 & 51 & 43 & 47 & 48 & 23 & 289 & \\
\hline FEMININO & \multirow{2}{*}{$11: 00-12: 00$} & 17 & 19 & 44 & 74 & 72 & 48 & 47 & 15 & 336 & \multirow{2}{*}{657} \\
\hline MASCULINO & & 22 & 26 & 61 & 50 & 59 & 46 & 41 & 16 & 321 & \\
\hline FEMININO & \multirow{2}{*}{$12: 00-13: 00$} & 16 & 20 & 43 & 64 & 68 & 52 & 49 & 16 & 328 & \multirow{2}{*}{672} \\
\hline MASCULINO & & 19 & 43 & 57 & 56 & 67 & 45 & 43 & 14 & 344 & \\
\hline FEMININO & \multirow{2}{*}{ 13:00-14:00 } & 9 & 18 & 32 & 45 & 51 & 43 & 39 & 9 & 246 & \multirow{2}{*}{515} \\
\hline MASCULINO & & 8 & 25 & 31 & 47 & 54 & 49 & 42 & 13 & 269 & \\
\hline FEMININO & \multirow{2}{*}{$-14: 00-15: 00$} & 7 & 15 & 32 & 37 & 34 & 24 & 19 & 10 & 178 & \multirow{2}{*}{348} \\
\hline MASCULINO & & 10 & 17 & 26 & 34 & 36 & 22 & 16 & 9 & 170 & \\
\hline FEMININO & \multirow{2}{*}{-15:00-16:00 } & 8 & 7 & 28 & 44 & 47 & 43 & 10 & 1 & 188 & \multirow{2}{*}{360} \\
\hline MASCULINO & & 9 & 8 & 39 & 36 & 41 & 24 & 10 & 5 & 172 & \\
\hline FEMININO & \multirow{2}{*}{$16: 00-17: 00$} & 9 & 7 & 21 & 32 & 56 & 31 & 38 & 8 & 202 & 355 \\
\hline MASCULINO & & 7 & 11 & 21 & 33 & 29 & 26 & 20 & 6 & 153 & (2) \\
\hline FEMININO & $17 \cdot 00-18.00$ & 16 & 16 & 41 & 66 & 62 & 46 & 41 & 9 & 297 & 571 \\
\hline MASCULINO & $11.00-10.00$ & 29 & 28 & 53 & 43 & 52 & 35 & 26 & 8 & 274 & דוד \\
\hline FEMININO & $18.00-19.00$ & 18 & 17 & 43 & 71 & 69 & 54 & 50 & 11 & 333 & 662 \\
\hline MASCULINO & $18.00-19.00$ & 23 & 36 & 61 & 52 & 64 & 43 & 37 & 13 & 329 & 000 \\
\hline FEMININO & (2) & 17 & 18 & 41 & 68 & 73 & 57 & 54 & 12 & 340 & \\
\hline MASCULINO & $79: 00-20: 00$ & 21 & 42 & 65 & 57 & 69 & 41 & 38 & 13 & 346 & 686 \\
\hline FEMININO & & 6 & 17 & 31 & 46 & 52 & 44 & 39 & 9 & 244 & \\
\hline MASCULINO & $20: 00-21.00$ & 8 & 24 & 32 & 49 & 57 & 46 & 42 & 11 & 269 & 513 \\
\hline FEMININO & & 1 & 12 & 29 & 32 & 41 & 37 & 34 & 8 & 194 & 395 \\
\hline MASCULINO & $21: 00-22.00$ & 2 & 15 & 27 & 33 & 44 & 39 & 31 & 10 & 201 & 390 \\
\hline & & & & & & & & TOTAL C & NER & FEMININO = & 3736 \\
\hline & & & & & & & TO & $T A L G \hat{E}$ & $R O I$ & ASCULINO = & 3727 \\
\hline & & & & & & & & & & TOTAL = & 7463 \\
\hline
\end{tabular}

Fonte: elaborado pelos autores (2018).

\section{GÊNERO/TOTALX HORA}

- feminaivo - mascuuno - Tota

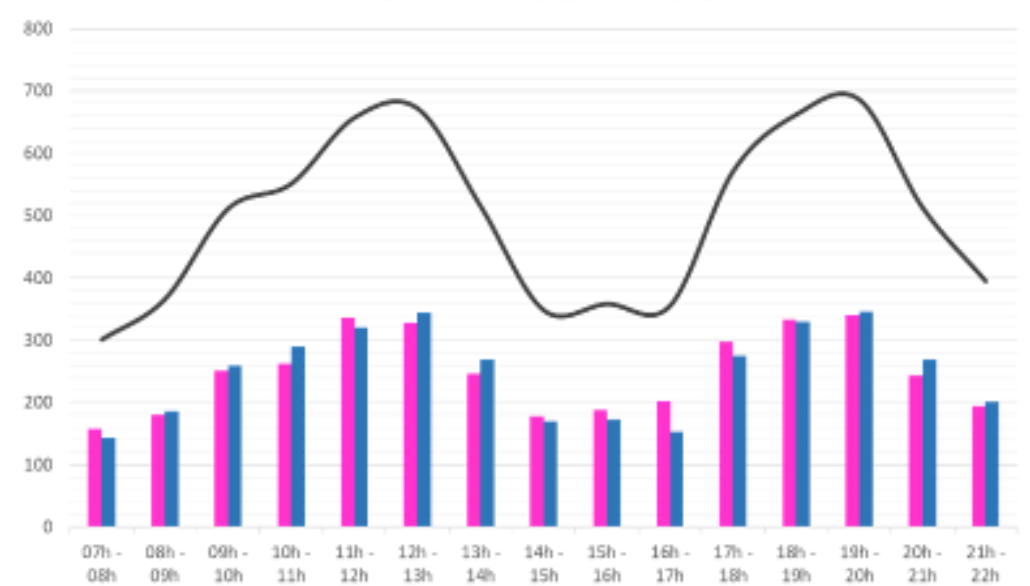

Gráfico 2 - Relação entre gênero feminino e masculino, total de pedestres e horário. Fonte: elaborado pelos autores (2018). 
Foi quantificado um total de 7.463 indivíduos no intervalo de tempo proposto. Sendo, 3.736 do gênero feminino e 3.727 do gênero masculino. Dessa forma, as mulheres ocupam um pouco mais as calçadas e circulações que o homem, porém com uma diferença insignificante.

O gráfico 2 ilustra de forma esquemática que das 15 horas de contagem, em 8 horas o gênero masculino foi o mais presente, 1 hora a mais que o gênero feminino. Os dois maiores períodos de circulação de pedestres foram de 10 às 13 horas e de 17 às 21 horas, basicamente, os horários de pico dessa área.

Outra estratégia empregada foi a observação e o diário (figura 4), a fim de identificar os acontecimentos e sinais comportamentais, as atividades estacionarias, para aonde as pessoas vão e onde ficam, qual a velocidade da circulação dos pedestres, quanto tempo gastam para cobrir distancias, qual o horário de maior fluxo. Durante a realização da contagem foi também realizado um diário de informações que foram relacionadas a dados coletado com outras técnicas utilizadas.

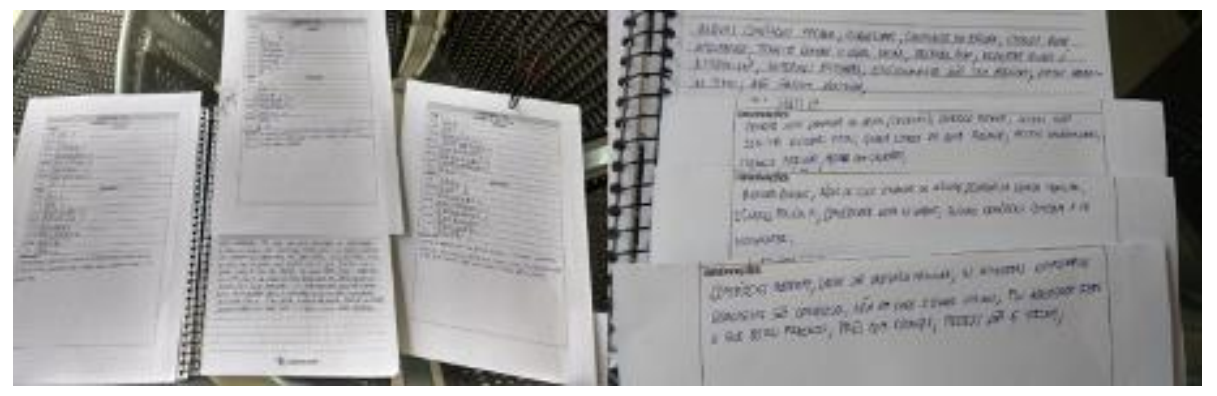

Figura 4 - Metodologia da observação e diário.

Fonte: elaborado pelos autores (2018).

A partir desse método foi possível acompanhar e relacionar os principais comportamentos das pessoas e, também, da logística que acontecem nas edificações da área. Jacobs (2000) descreve o que ela chama de "balé das ruas", em que vários atores, com os mais diversos propósitos, saem às ruas em horários diversificados para as mais diferentes atividades. Essas atividades interagem entre si e de alguma forma acabam complementando-se, formando uma teia de interação social e cuidados mútuos.

\section{O ENSAIO PROJETUAL NA AV. DR. JAIR DE ANDRADE}

Considerando os estudos teóricos e o diagnóstico realizados, percebe-se o potencial da região para diversidade de usos, presença de transportes ativos, acolhimento das bicicletas, calçadas razoavelmente dimensionadas, serviços e comércios próximos às moradias. Para tanto, no ensaio projetual ilustrado, foi necessário proteger o pedestre, criar novos espaços públicos, aumentar a arborização da via, ativar a presença de ciclistas e reafirmar o lugar do automóvel.

Visando um melhor entendimento das necessidades do objeto de estudo foi desenvolvido uma tabela (2) que ilustra as potencialidades e fragilidades a fim de gerar diretrizes que resultam em ações. 
Tabela 2- Potencialidades, fragilidades, diretrizes e ações.

\begin{tabular}{|c|c|c|c|c|}
\hline & PONTENCIALIDADES & FRAGILIDADES & DIRETRIZES & AÇÕES \\
\hline \multirow{4}{*}{$\begin{array}{l}\text { 岁 } \\
\text { 曷 } \\
\text { 욤 }\end{array}$} & $\begin{array}{c}\text { Avenida como eixo de conexão } \\
\text { Ruas paralelas com acesso ao } \\
\text { transporte público } \\
\end{array}$ & $\begin{array}{c}\text { Ponto de ônibus sob a ciclofaixa, } \\
\text { parada de ônibus diminui o } \\
\text { tamanho da faixa da via }\end{array}$ & Transporte fluído & $\begin{array}{c}\text { Realocar a faixa de transporte } \\
\text { público somente para as ruas } \\
\text { paralelas } \\
\end{array}$ \\
\hline & $\begin{array}{l}\text { Ciclofaixa presente ao longo da } \\
\text { avenida }\end{array}$ & $\begin{array}{l}\text { Falta de sinalização, carros não } \\
\text { respeitam a marcação, espaço } \\
\text { compartilhado sem proteção }\end{array}$ & Acolher bicicletas & $\begin{array}{l}\text { Criação de ciclovia com canteiro } \\
\text { de divisão }\end{array}$ \\
\hline & $\begin{array}{c}\text { Ruas anexas a avenida sem grande } \\
\text { fluxo de automovéis }\end{array}$ & $\begin{array}{c}\text { Falta de segurança e prioriadade } \\
\text { de pedestre em ruas anexas a } \\
\text { anvenida }\end{array}$ & Eleger prioridades & $\begin{array}{l}\text { Ruas preferenciais de pedestre e } \\
\text { alargamento das calçadas }\end{array}$ \\
\hline & $\begin{array}{l}\text { Projeto calçada legal implementada } \\
\text { em grande parte da avenida }\end{array}$ & \begin{tabular}{|c|}
$\begin{array}{c}\text { Falta de manutenção e reparo das } \\
\text { calçadas, faixas de pedestres e } \\
\text { travessias }\end{array}$ \\
\end{tabular} & Acessibilidade & $\begin{array}{c}\text { Aumento da calçada, sinalização } \\
\text { adequada, piso continuo }\end{array}$ \\
\hline \multirow{4}{*}{ 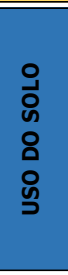 } & $\begin{array}{c}\text { Diversidade de usos de diferente } \\
\text { porte na avenida e em ruas } \\
\text { adjacentes }\end{array}$ & $\begin{array}{l}\text { Fachadas opacas e sem conexão } \\
\text { com a avenida, vazios urbanos }\end{array}$ & Mesclar usos & $\begin{array}{l}\text { Incentivo o uso de edificios mistos, } \\
\text { fachadas ativas, diferentes usos }\end{array}$ \\
\hline & $\begin{array}{c}\text { Vagas presentes ao longo da } \\
\text { avenida principal }\end{array}$ & Sem rotatividade de veiculos & Adequar estacionamento & $\begin{array}{l}\text { Realocar faixas de estacionamento } \\
\text { e utilização do parquímetro }\end{array}$ \\
\hline & $\begin{array}{c}\text { Conexão com a orla, diversidades } \\
\text { de uso atrativos no entorno }\end{array}$ & $\begin{array}{c}\text { Falta de espaço público e mobiliario } \\
\text { urbano }\end{array}$ & Bons espaços & \begin{tabular}{|c|}
$\begin{array}{c}\text { Implantação de mobiliario urbano, } \\
\text { utilização de vazios voltados a } \\
\text { sociedade }\end{array}$ \\
\end{tabular} \\
\hline & Forte caráter simbolico da avenida & $\begin{array}{c}\text { Depredação e deteorização dos } \\
\text { espaços }\end{array}$ & $\begin{array}{c}\text { Faces de ruas agradáveis e } \\
\text { singulares }\end{array}$ & $\begin{array}{l}\text { Incentivo a eventos e } \\
\text { empoderamento da avenida por } \\
\text { meio de atividades periódicas }\end{array}$ \\
\hline \multirow{2}{*}{ 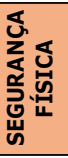 } & $\begin{array}{l}\text { Lombada como dispositivo de } \\
\text { redução de velocidade }\end{array}$ & $\begin{array}{l}\text { Acidentes causados pela falta de } \\
\text { respeito a velocidade permitida }\end{array}$ & Automovél em seu lugar & $\begin{array}{l}\text { Avenida com sinalização, } \\
\text { equipamentos para redução de } \\
\text { velocidade, vagas bem definidas }\end{array}$ \\
\hline & $\begin{array}{c}\text { Marquises de comércios auxiliam na } \\
\text { proteção }\end{array}$ & $\begin{array}{l}\text { Diversos obstaculos impostos pelo } \\
\text { comércio e condições do passeio }\end{array}$ & Proteger o pedestre & $\begin{array}{l}\text { Calçada deve ser livre de } \\
\text { obstáculos, proteção do sol e da } \\
\text { chuva, assentos, calçadas largas }\end{array}$ \\
\hline \multirow{3}{*}{ 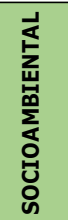 } & $\begin{array}{c}\text { Ao longo da avenida há existencia } \\
\text { de arborização }\end{array}$ & $\begin{array}{c}\text { Falta de espaço para o plantio, } \\
\text { descaso com as árvores existentes }\end{array}$ & Plantar árvores & $\begin{array}{l}\text { Auxiliar na filtragem e purificação } \\
\text { do ar, geração de sombra, } \\
\text { aumento da biodiversidade }\end{array}$ \\
\hline & $\begin{array}{c}\text { Evitar alagamentos inviabilizando o } \\
\text { uso da via }\end{array}$ & $\begin{array}{l}\text { Desgaste da via e risco a saúde } \\
\text { dos transeuntes }\end{array}$ & Escoar água da chuva & $\begin{array}{l}\text { Jardins filtrantes, área de } \\
\text { escoamento aumentada }\end{array}$ \\
\hline & $\begin{array}{l}\text { Canal faz conexão com diferentes } \\
\text { pontos da cidade }\end{array}$ & Funciona como despejo de residuos & Conexão canal com a via & $\begin{array}{l}\text { Interligar o canal as vias como } \\
\text { opção de locomoção, parque linear }\end{array}$ \\
\hline
\end{tabular}

Fonte: elaborado pelos autores (2018).

A proposta baseou-se no alargamento das esquinas e das calçadas, na alteração na rota de transporte público, na inserção de paginação de piso diferenciada, na requalificação de muros opacos, na inserção de mobiliários e arborização/vegetação, na ocupação de vazios urbanos e na transformação da ciclofaixa em ciclovia. O projeto foi vislumbra aumentar o índice de caminhabilidade na avenida através da valorização do transporte ativo.

A principal intervenção foi a ampliação das vias de pedestre sobre o leito carroçável e a implantação da ciclovia, auxiliando, assim, nas oportunidades para deslocamento de pedestres e ciclistas. A seguir, a Figura 5 ilustra o corte esquemático que exemplifica a nova logística utilizada no projeto bem como, através do levantamento do quantitativo de metros quadrados da via, a relação entre os espaços destinados a pedestre, ciclistas e veículos da situação atual e das propostas de intervenção. 


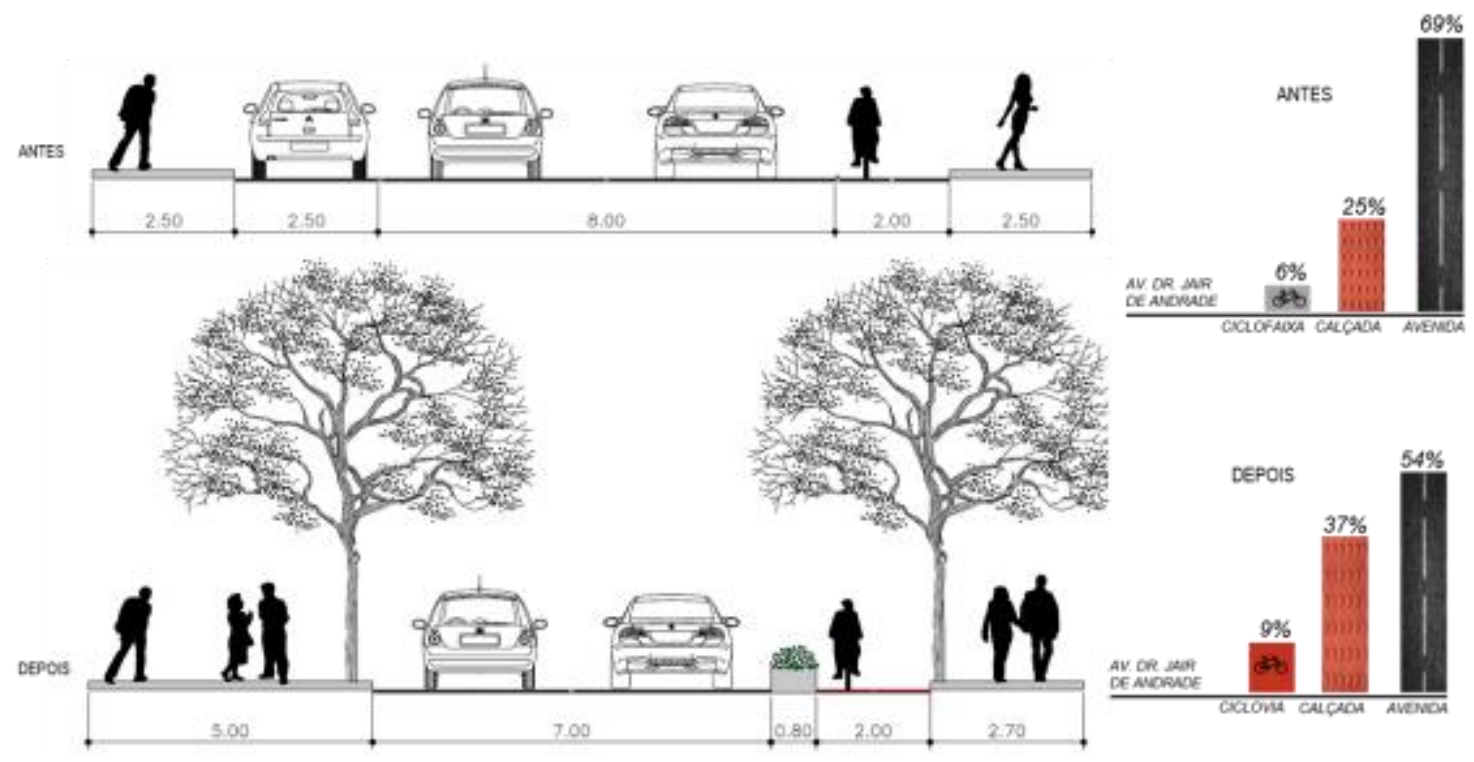

Figura 5 - Corte na Av. Dr. Jair de Andrade, antes $x$ depois. Fonte: elaborado pelos autores (2018).

As extensões do meio-fio são extensões da calçada, geralmente em interseções, reduzindo a distância de travessia e melhorando a visibilidade dos pedestres (figura 6). Dessa forma, as esquinas de todas as quadras do recorte foram expandidas a fim de melhorar as condições dos pedestres. Uma expansão da linha do meio-fio para dentro da faixa de rolamento (geralmente uma faixa de estacionamento) na esquina ou no meio da quadra pode reduzir a velocidade dos veículos que fazem conversão e oferecer proteção aos pedestres (WRI, 2017).

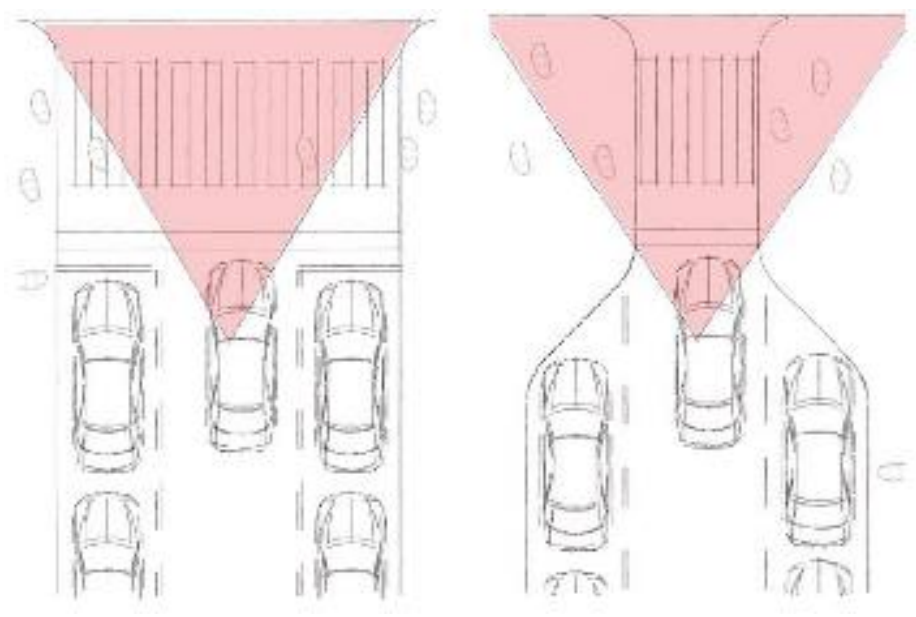

Figura 6 - Ângulo de visibilidade nas esquinas.

Fonte: WRI, 2017.

Segundo Speck (2016), ruas conectadas próximos a pontos de transporte coletivo e ao longo de corredores de ônibus possibilitam distâncias menores a serem percorridas pelos pedestres. Sendo assim, as paradas de ônibus presentes na avenida, que causam interrupções na ciclovia, foram realocados para as ruas vizinhas. Também foram propostas paginação diferenciada em algumas faixas de transição e/ou serviço, de modo a contrastar e criar um espaço de permanência para os pedestres, dando maior identidade ao ambiente, conforme ilustrada na figura 7. 


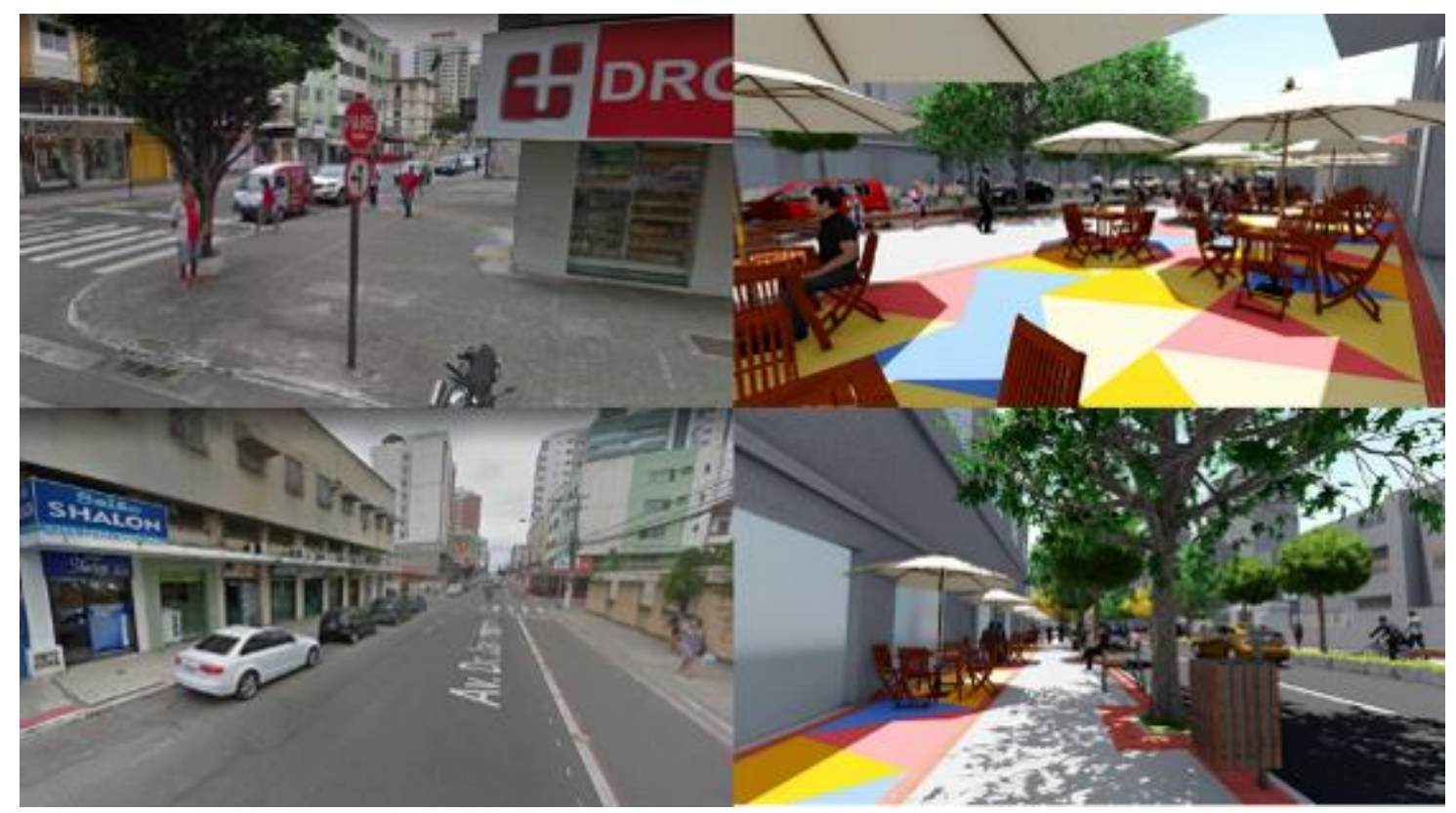

Figura 7 - Paginação de piso e realce faixas de transição (realidade x proposta) Fonte: elaborado pelos autores (2018)

As interseções elevadas são elevações da via, no mesmo nível do pavimento das calçadas, que buscam, além da maior conexão e acessibilidade dos deslocamentos a pé, reduzir a velocidade dos carros onde os pedestres atravessam. Sendo assim, foi proposta que as interseções, principalmente nas áreas de maior circulação de pessoas, fossem elevadas e também sinalizadas para melhor visibilidade (Figura 8).

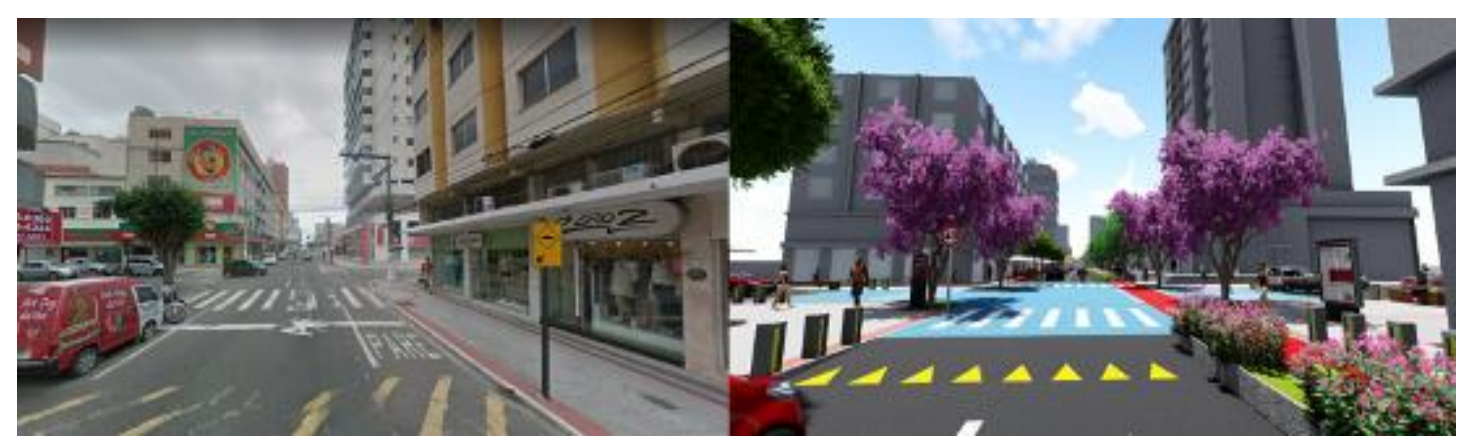

Figura 8 - Inserção de interseções elevadas (realidade x proposta)

Fonte: elaborado pelos autores (2018)

Nas calçadas, o caminho percorrido pelos pedestres envolve também outros espaços urbanos, como interseções e travessias. Além das interseções elevadas, as conexões seguras por meio da conectividade, esquinas, faixa de travessia de pedestres propiciam deslocamentos a pé contínuos e conectados. É importante que as conexões entre esses elementos sejam acessíveis e seguras para criar uma rede de mobilidade a pé (WRI BRASIL, 2017).

Nos trechos de fachadas opacas e muradas foi proposta a implantação de módulos de apoio em container para usos comerciais, de modo a aumentar a concentração de indivíduos. Outra estratégia foi a de utilizar a cor e a arte gráfica nos revestimentos de piso e fachadas (Figura 9). 


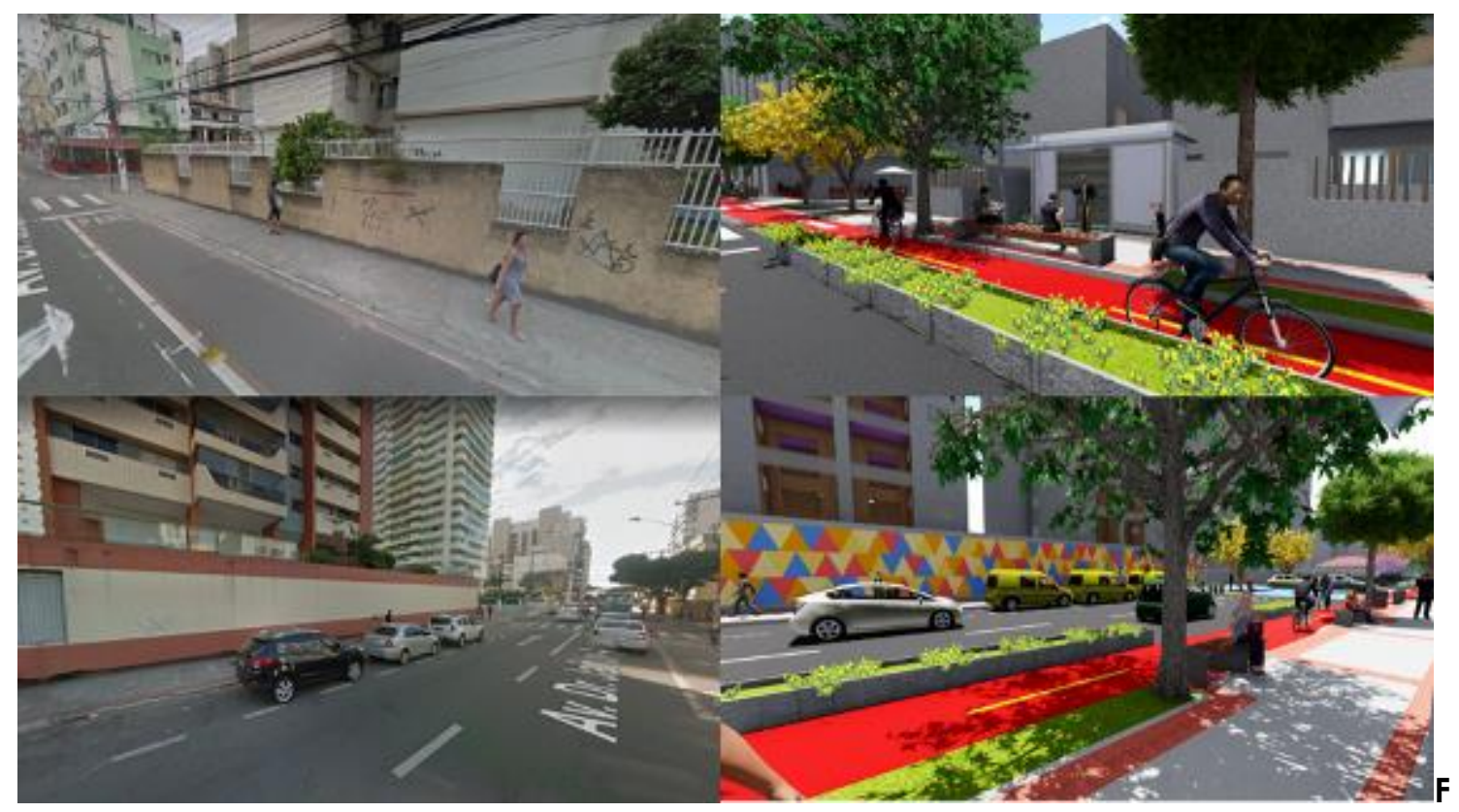

Figura 9 - Requalificação dos muros ao longo da avenida (realidade x proposta)

Fonte: elaborado pelos autores (2018)

$\mathrm{Na}$ avenida, atualmente, há presença de ciclofaixa que não promovem segurança dos ciclistas em relação aos carros, tanto que muitos veículos utilizam a faixa como parada e/ou estacionamento prejudicando a circulação. Dessa forma, a proposta indica que uma parte da via seria destinada a implantação de uma ciclovia segregada por canteiro e com pintura de piso contrastante (figura 10). Os objetivos das ciclovias protegidas são a de separar fisicamente os ciclistas do tráfego motorizado e garantir a sua mobilidade e segurança (WRI, 2017).

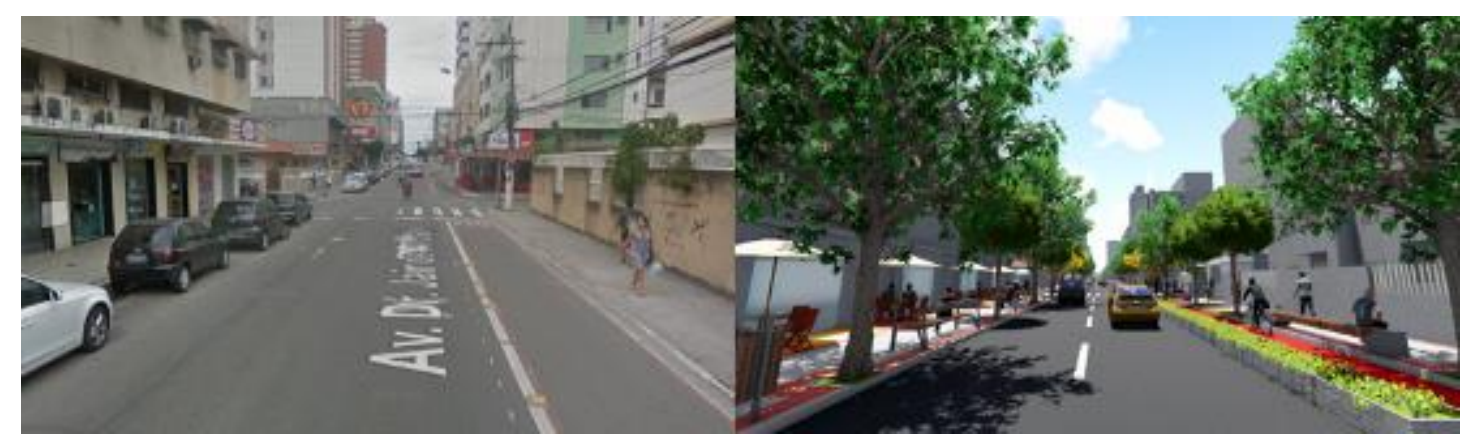

Figura 10 - Transformação da ciclofaixa em ciclovia (realidade x proposta)

Fonte: elaborado pelos autores (2018)

Um dos objetivos desse trabalho é, através do projeto, tornar a Av. Dr. Jair de Andrade mais atrativa em relação a vegetação e mobiliário, que por meio deles proporcione um ambiente no qual as pessoas se sentem confortáveis. Um espaço atraente não é medido pelo número de pessoas que transitam na calçada, mas pela ambiência que o espaço urbano transmite, pela facilidade de deslocamento, pela possibilidade de permanência e pelo significado que é criado no lugar. O ambiente e a disposição do mobiliário urbano são elementos significativos para o conforto e bem-estar no espaço urbano. As fachadas ativas dos prédios e as múltiplas entradas e vitrines podem tornar a experiência da caminhada mais agradável. A vegetação e o tipo de pavimento associado a locais de descanso, se bem selecionados, podem 
tornar as calçadas locais de interação social, proporcionando mais vida - e, consequentemente, segurança - para a cidade (WRI BRASIL, 2017). A seguir figura 11 que ilustra a arborização ao longo da avenida.

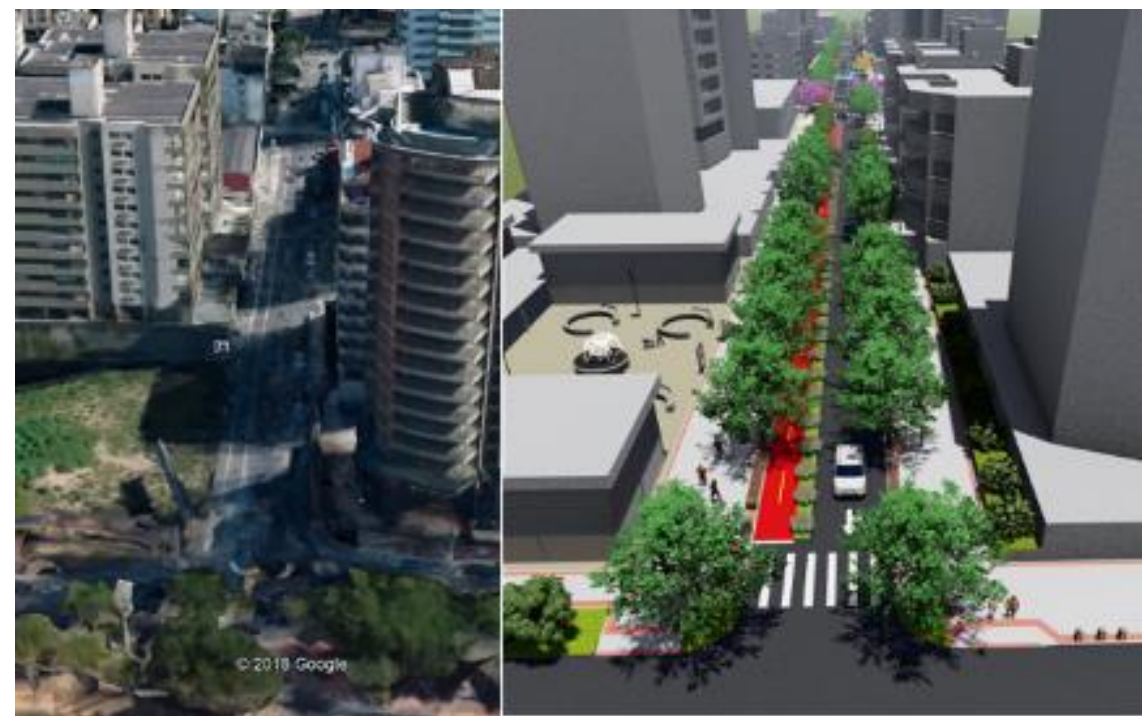

Figura 11 - Arborização na avenida (realidade x proposta)

Fonte: elaborado pelos autores (2018)

Ainda foram propostos ocupação para dois vazios urbanos situados no cruzamento com a Av. Dr. Jair de Andrade. No primeiro foi idealizado a implantação de um edifício híbrido com os afastamentos diferenciados para melhor interação com o entorno. A presença do edifício contanto com lojas, salas comerciais e moradias fomenta a atividade de moradores e, também, pessoas de outros lugares. Além disso, no final na via com encontro da orla há um vazio urbano que foi idealizado a implantação de um centro gastronômico aberto em forma de mercado. O centro teria conexão com a orla pela proximidade e, também, tornando-se uma referência para quem transita pelas localidades. A seguir, a figura 12, ilustra o preenchimento desses espaços.

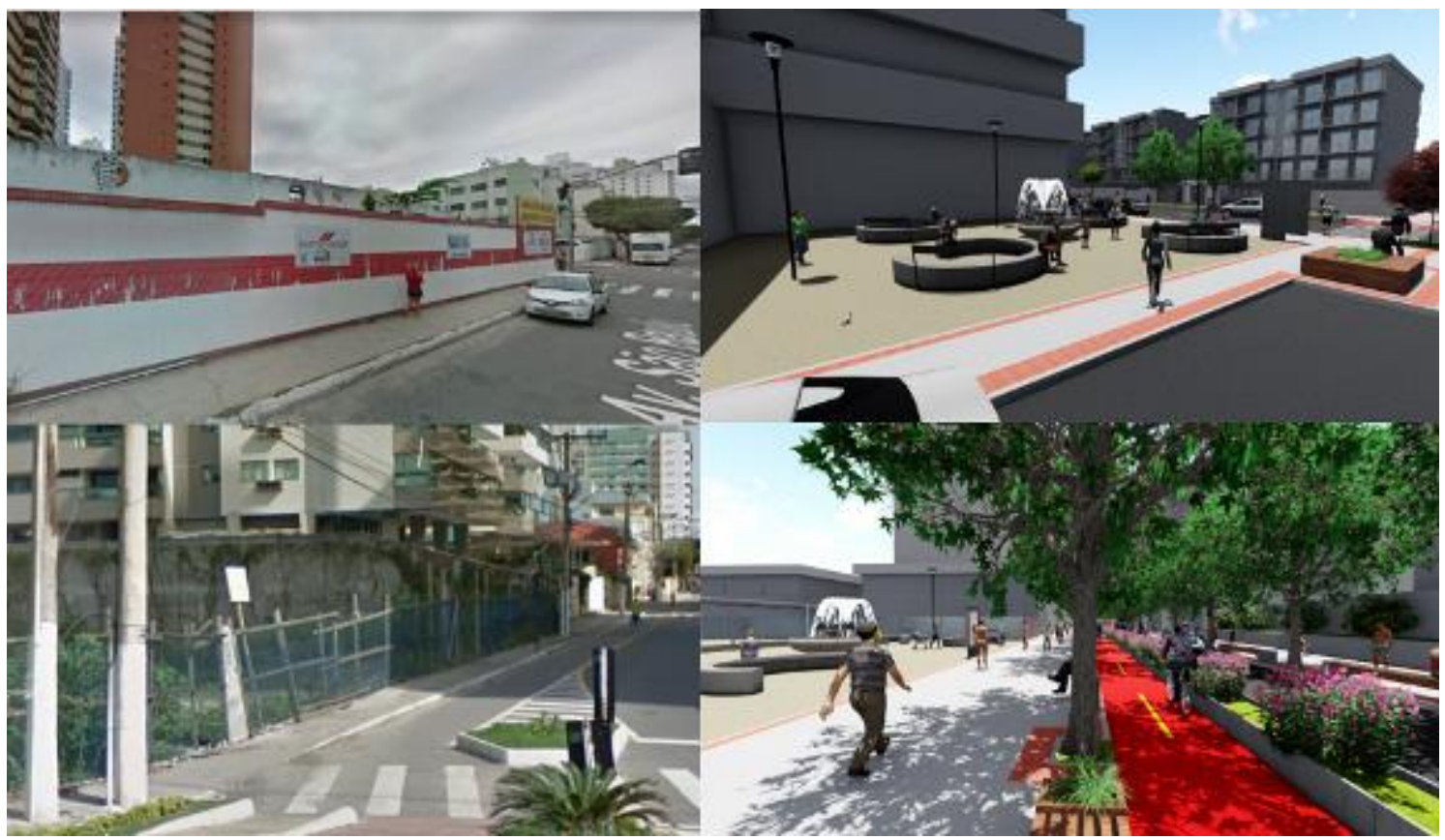

Figura 12 - Preenchimento dos vazios urbanos (realidade x proposta)

Fonte: elaborado pelos autores (2018) 
O projeto foi setorizado em trechos para melhor ampliação do desenho das calçadas e exposição das perspectivas. Dessa forma, a seguir será demonstrado os recortes da planta humanizada com suas respectivas perspectivas e observações.

\subsection{Trecho 01}

Neste trecho (figura 13) foi idealizado a implantação de uma banca de revista no afastamento do terreno, criação de paginação diferenciada na faixa de transição, dentre outras estratégias citadas anteriormente (figura 14).

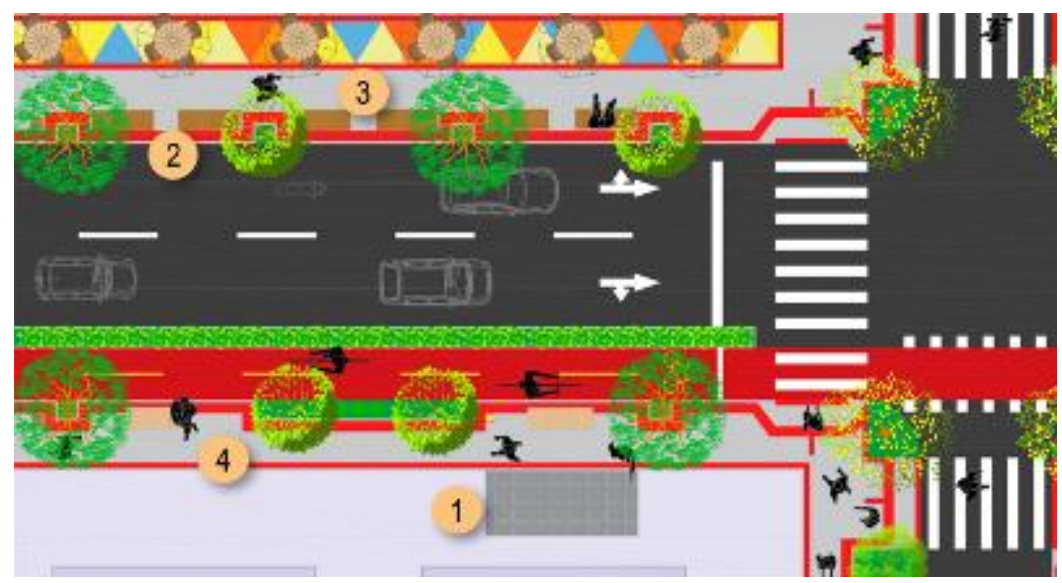

Figura 13- Planta humanizada trecho 01.

Fonte: elaborado pelos autores (2018)

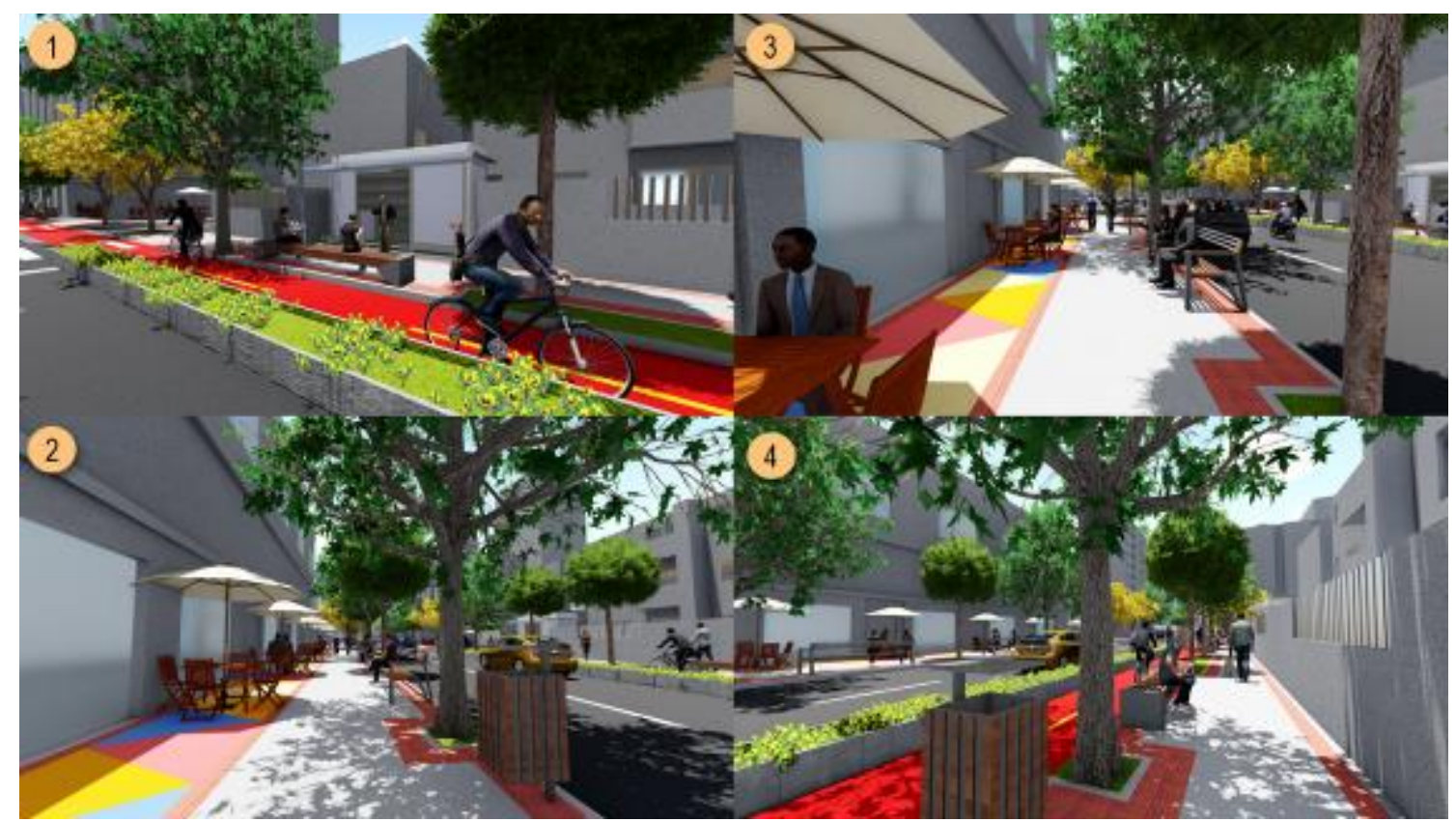

Figura 14- Perspectivas do trecho 01.

Fonte: elaborado pelos autores (2018)

\subsection{Trecho 02}

O afastamento frontal do edifico existem que possui uma galeria de lojas no térreo influenciou na decisão de locar mesas e cadeiras na faixa de transição criando, assim, um espaço de permanência. Além disso, o espaço na calçada utilizado pelo bar foi reajustado de maneira a não bloquear a passagem. 0 cruzamento nessa área foi elevado, visto o grande número de acidentes 
relatados anteriormente. A circulação de pedestres no trecho 02 é potencializada pelos usos diversificados. Figuras 15 e 16, respectivamente, ilustram as estratégias.

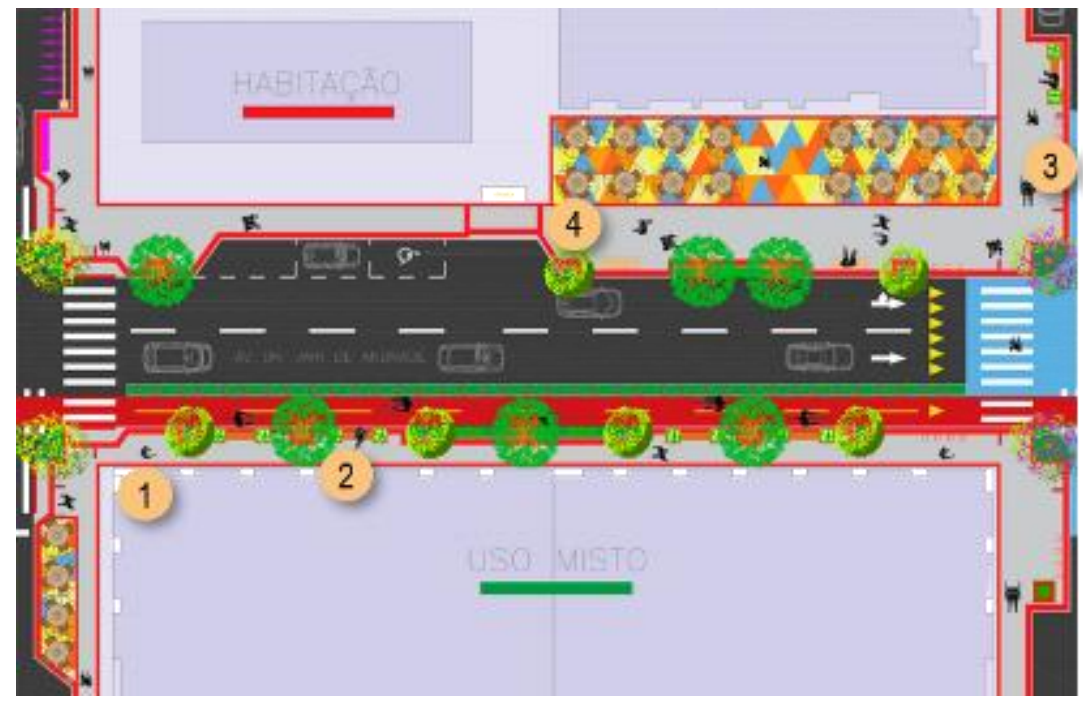

Figura 15 - Planta humanizada trecho 02.

Fonte: elaborado pelos autores (2018)

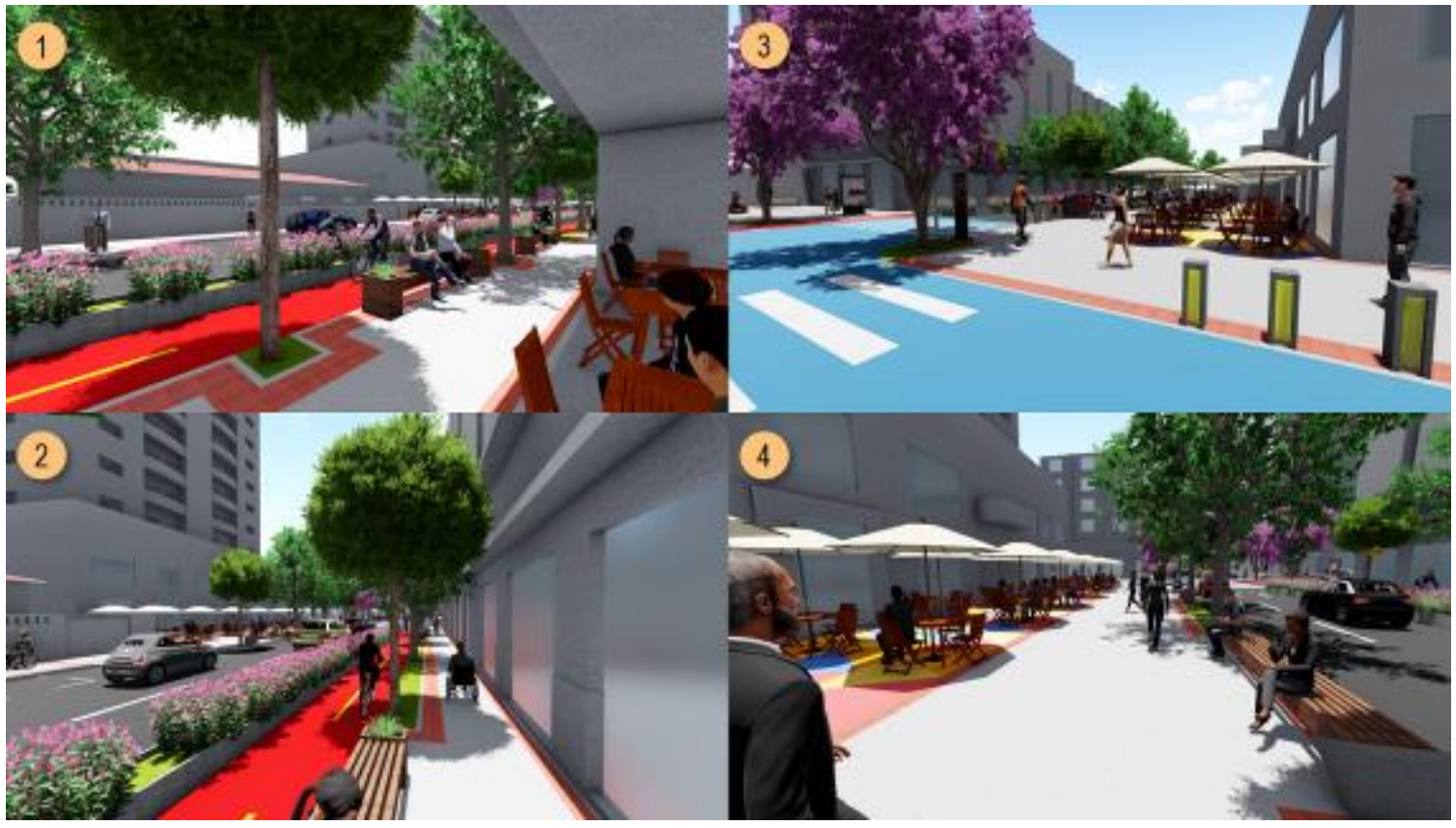

Figura 16 - Perspectivas do trecho 02.

Fonte: elaborado pelos autores (2018)

\subsection{Trecho 03}

Trecho de transição de pedestres (figura 17) por conta de estar entre dois supermercados e dos dois lados da via conter uso mistos e comércio. Dessa forma, espaços de permanências foram destacados. O estacionamento da farmácia serve de apoio para eventuais food truck que fornecem serviços para os transeuntes (figura 18). 


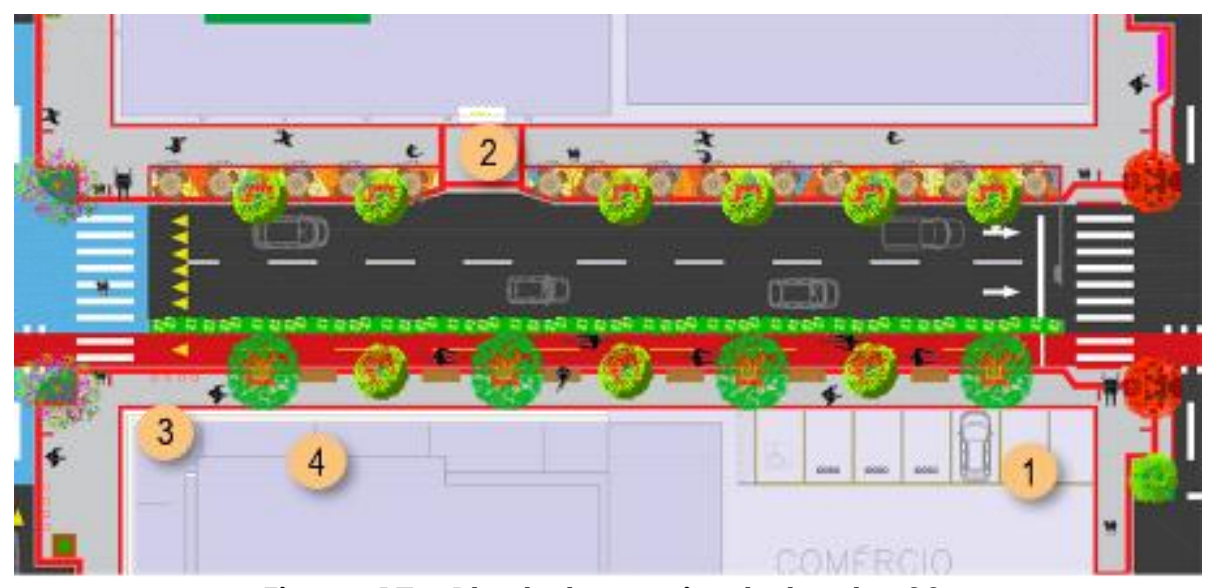

Figura 17 - Planta humanizada trecho 03.

Fonte: elaborado pelos autores (2018)

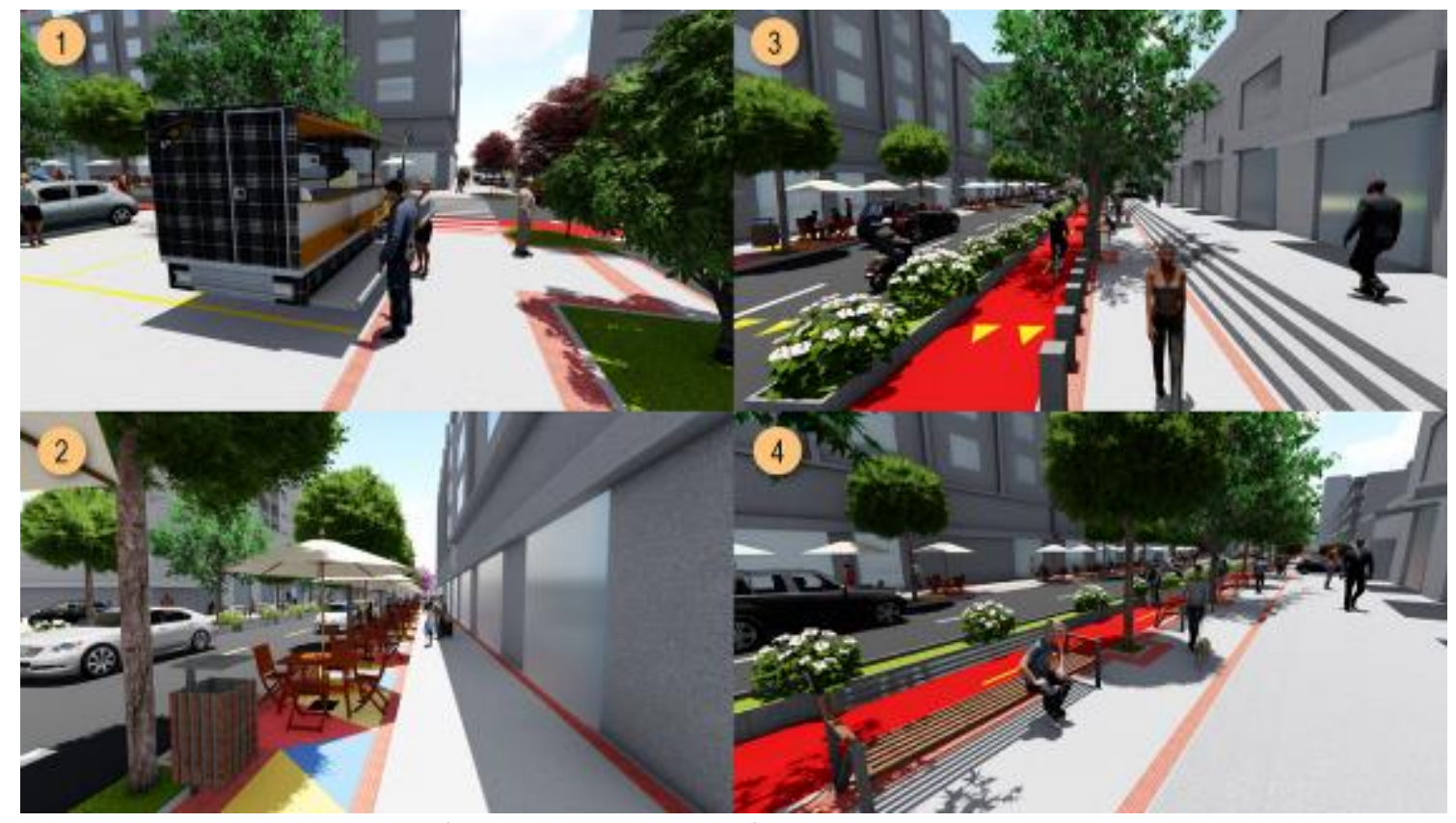

Figura 18 - Perspectivas do trecho 03.

Fonte: elaborado pelos autores (2018)

\subsection{Trecho 04}

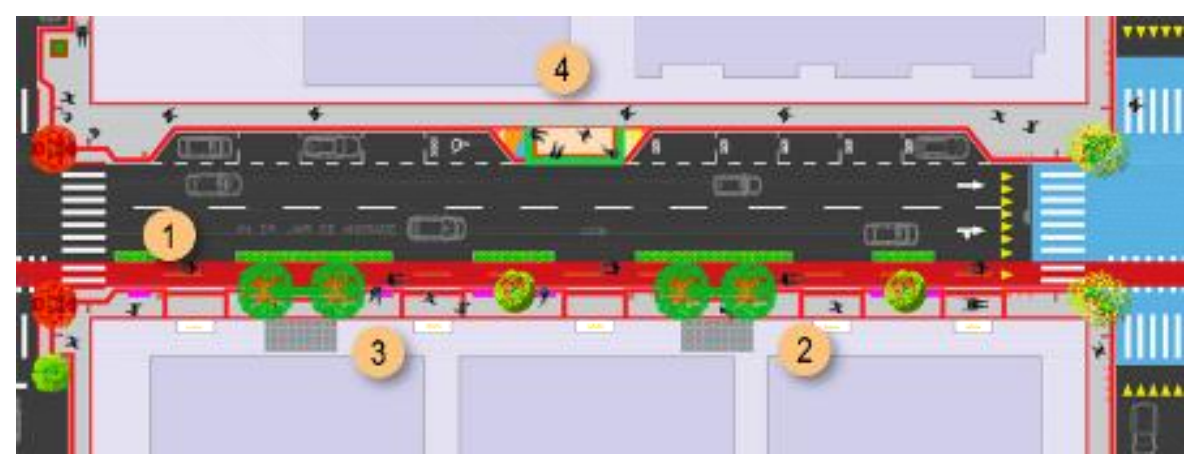

Figura 19 - Planta humanizada trecho 04.

Fonte: elaborado pelos autores (2018)

Nessa área (figura 19) foi idealizado a locação de vagas removidas e inserção de pontos de taxi. Sugere-se a requalificação dos muros com implantação de 
módulos de apoio e a paginação de piso ganha destaque ao ser representada no muro, com princípio de levar identidade ao local (figura 20). Allém disso, a estrutura de parklet serve para descanso e espera. Um edifício híbrido ocupando um vazio é aberto para rua.

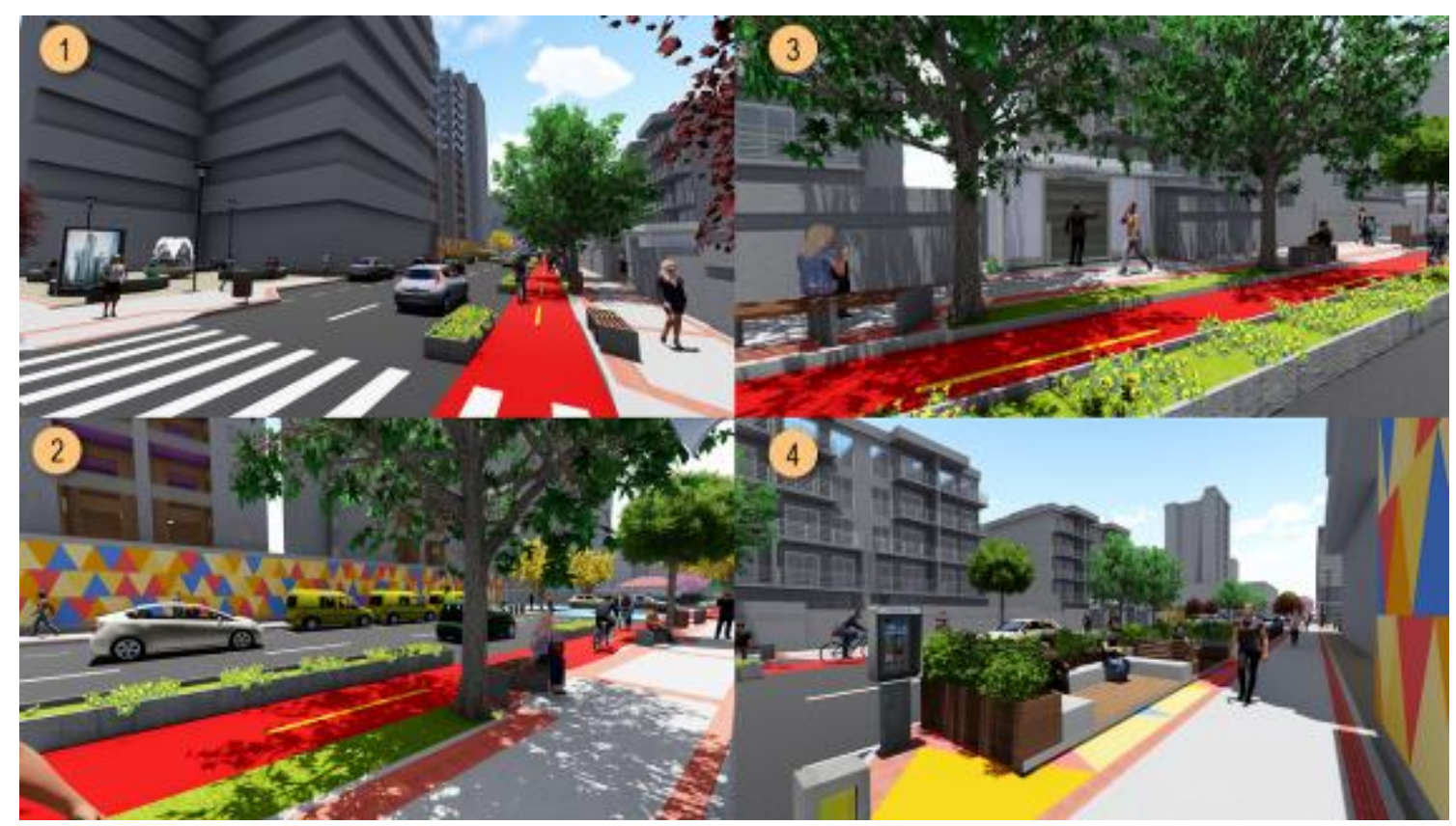

Figura 20 - Perspectivas do trecho 04.

Fonte: elaborado pelos autores (2018)

\subsection{Trecho 05}

Um lado da via destinado a vagas e paklet na proximidade do cruzamento elevado. O outro lado foi arborizado, implantado mobiliário e alargamento da calçada. Figuras de referência (21 e 22) em planta e perspectiva a seguir.

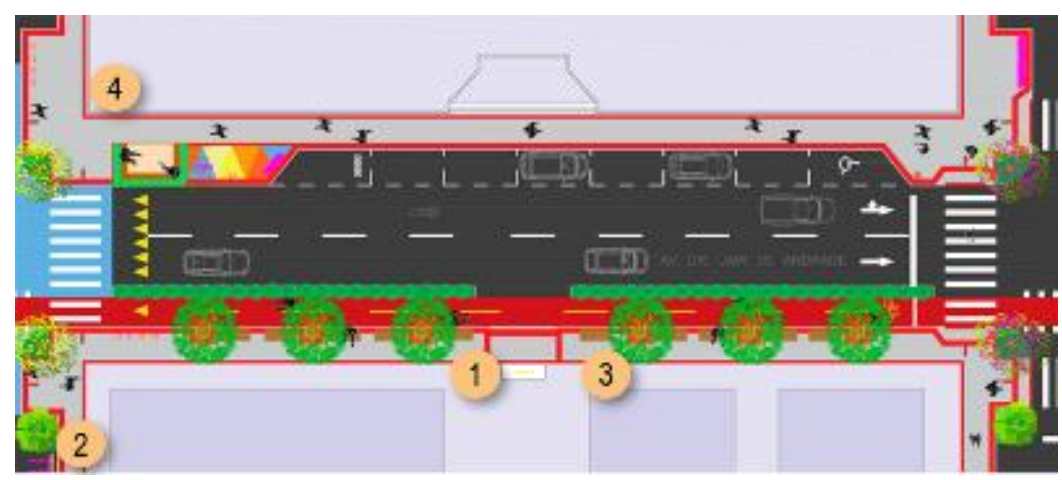

Figura 21 - Planta humanizada trecho 05.

Fonte: elaborado pelos autores (2018) 


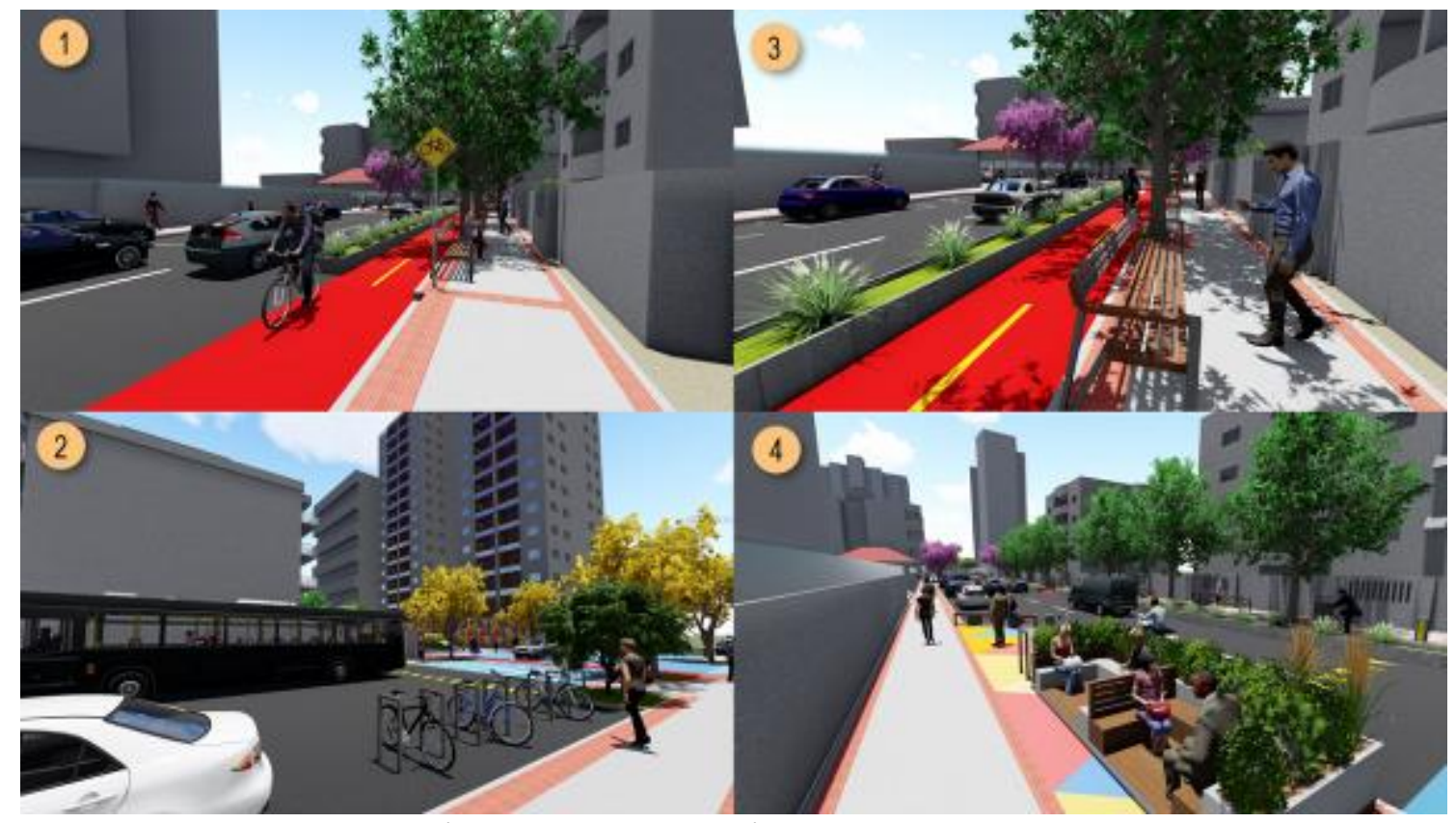

Figura 22 - Perspectivas do trecho 05.

Fonte: elaborado pelos autores (2018)

\subsection{Trecho 06}

O trecho 06 (figura 23) conta com uma galeria de lojas, restaurante e habitações. Dessa forma, foi feito um afunilamento da via para uma faixa, alargando a calçada com o objetivo de ser uma conexão a orla (figura 24).

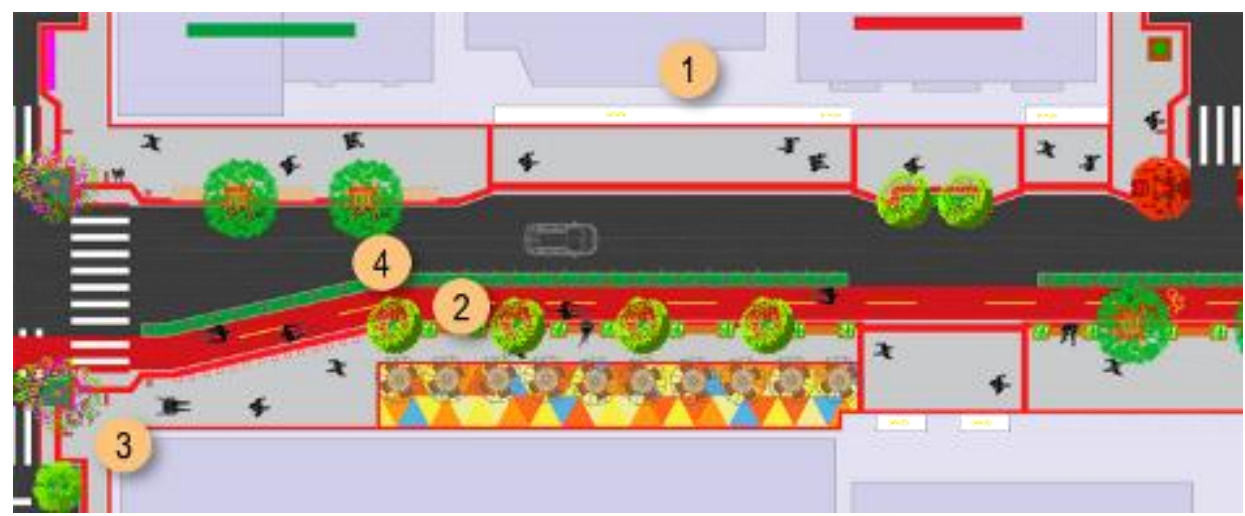

Figura 23 - Planta humanizada trecho 06.

Fonte: elaborado pelos autores (2018) 


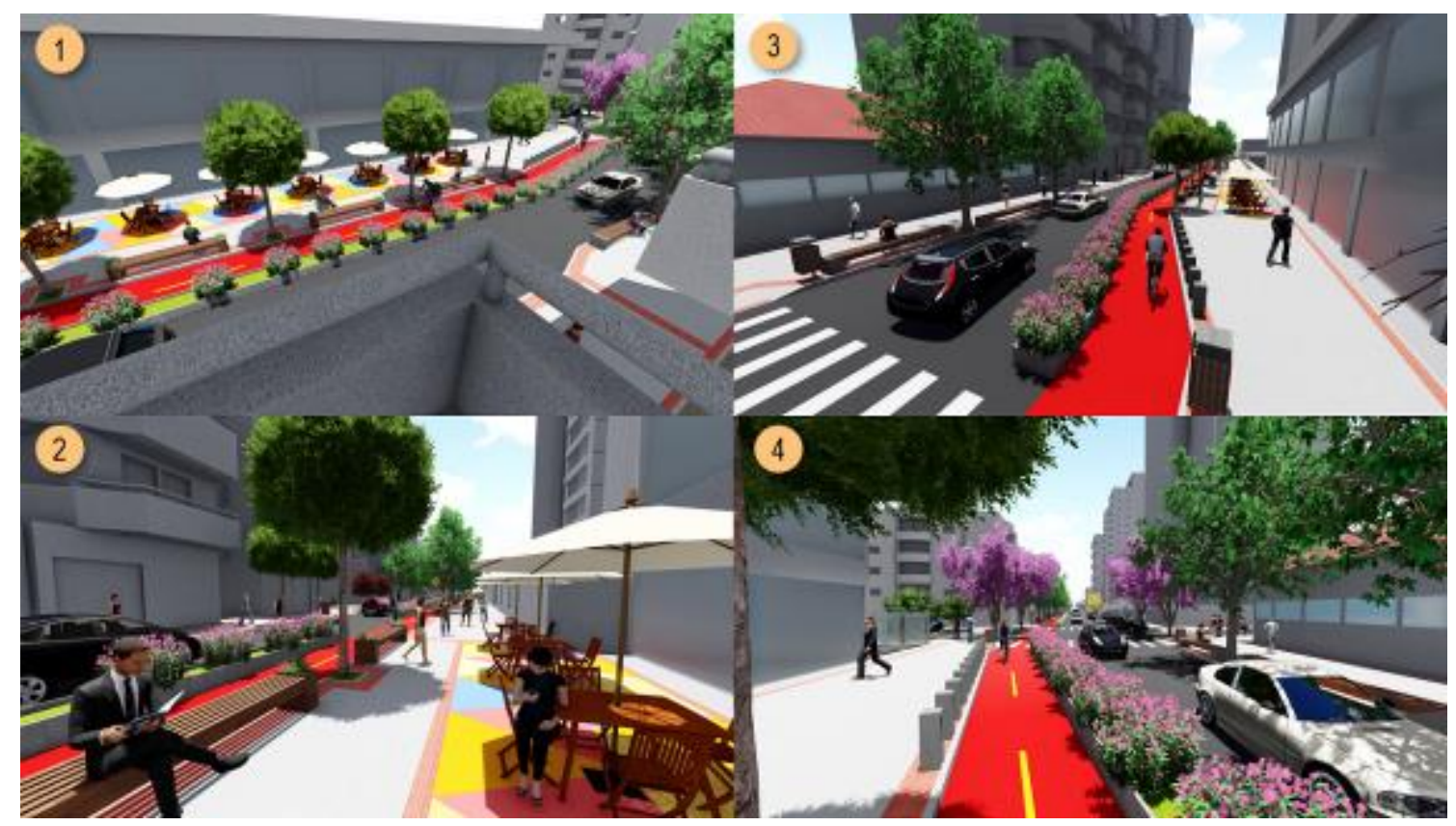

Figura 24 - Perspectivas do trecho 06.

Fonte: elaborado pelos autores (2018)

\subsection{Trecho 07}

No trecho 07 (figura 25) foi reforçada a conexão Av. Dr. Jair de Andrade $x$ Orla, visto que muitos pedestres utlizam esse acesso. Dessa forma, com o afunilamento da via e a expansão da calçada é possível criar um espaço de vivência ao longo do trecho. Além disso, a inserção do centro gastronômico no terreno vazio fomenta a ativiade pesqueira, já existente na região, e serve como mais uma opção para uso. Figura 26 de referência das perspectivas desse trecho, a seguir.

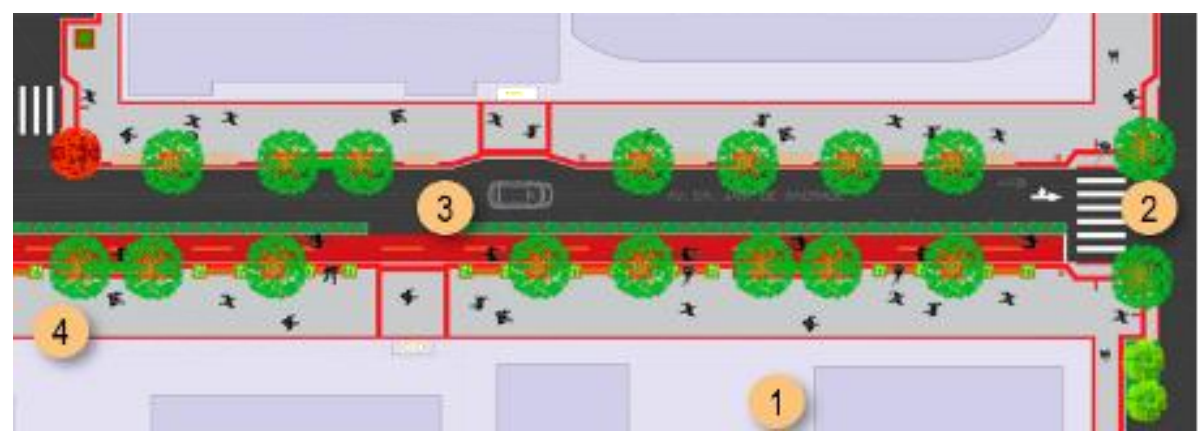

Figura 25 - Planta humanizada trecho 07.

Fonte: elaborado pelos autores (2018) 


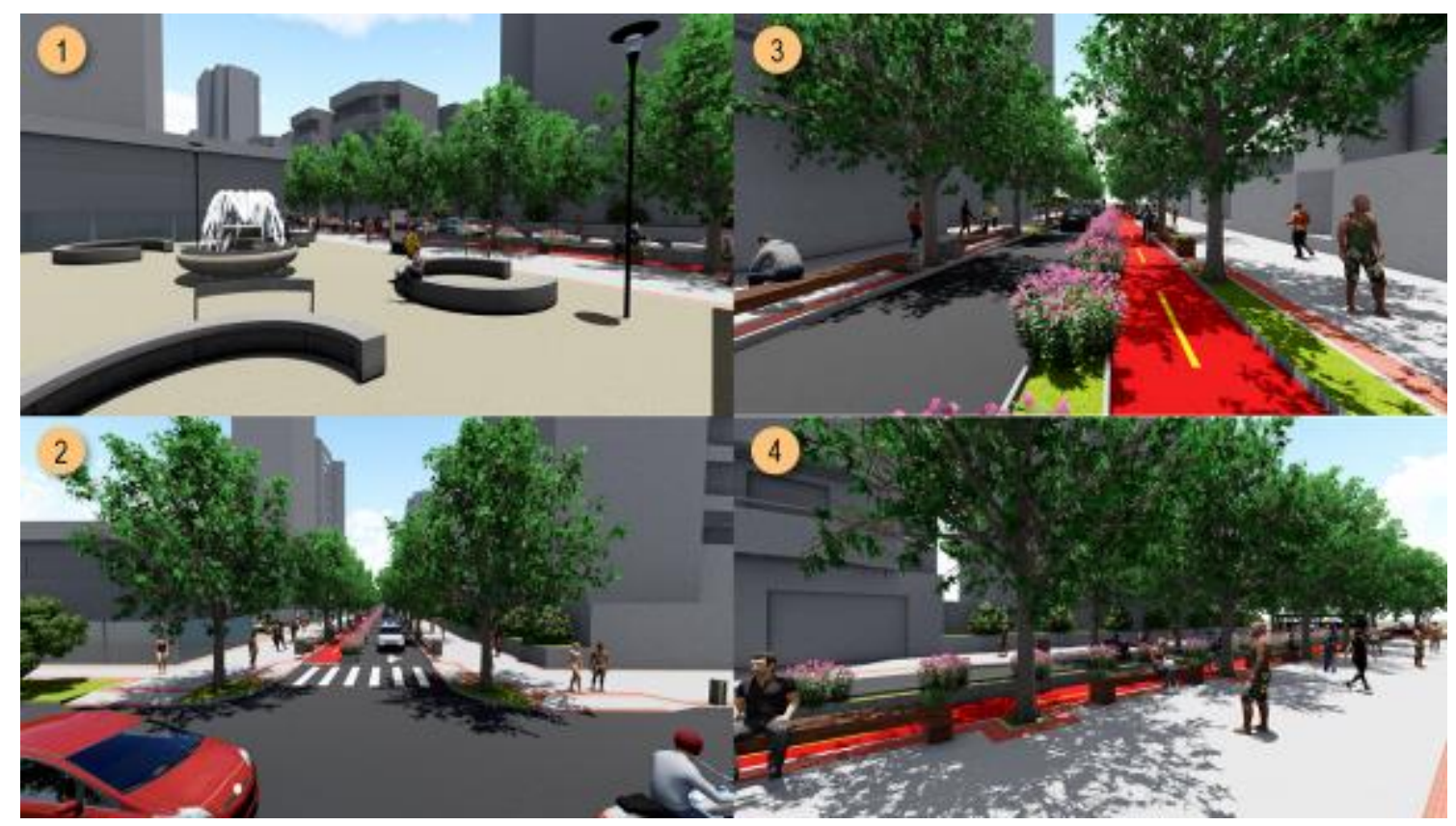

Figura 26 - Perspectivas do trecho 06.

Fonte: elaborado pelos autores (2018)

\section{CONSIDERAÇÕES FINAIS}

O entendimento da calçada como um espaço urbano dedicado para a convivência entre pessoas é fundamental para valorizar a importância dos princípios apresentados neste artigo. O correto dimensionamento da calçada de acordo com o fluxo de pedestres é essencial para configurar uma rede de caminhos que estimulem os deslocamentos a pé.

As calçadas precisam compor um ambiente confortável para a convivência entre as pessoas, com mobiliário e vegetação bem planejados. O pavimento deve ser firme e contínuo para conferir conforto e segurança aos pedestres, incluindo facilidades para pessoas com mobilidade reduzida. As calçadas são espaços para a circulação e a permanência dos pedestres e são compostas por elementos que vão além da pavimentação de faixas laterais às vias de tráfego de automóveis.

As fachadas das construções também influenciam a experiência dos pedestres, bem como a iluminação e a drenagem eficiente da água da chuva. Além disso, o ambiente urbano por onde os pedestres caminham deve se comunicar através de uma sinalização coerente.

Este artigo ilustra estratégias para a construção de espaços qualificados para pedestres, baseados em uma revisão da literatura nacional e internacional de forma a frisar a valorização daqueles que devem ser prioridade na locomoção urbana.

\section{REFERÊNCIAS}

GEHL, Jan; Cidade Para Pessoas. 1. ed. São Paulo: Perspectiva, 2013. 261 p. (Arquitetura e Urbanismo)

GEHL, Jan; SVARRE, Birgitte. A Vida na Cidade - Como Estudar. 1. ed. São

Paulo: Perspectiva, 2018. 148 p. (Arquitetura e Urbanismo) 
GHIDINI, Roberto. A Caminhabilidade: Medida Urbana Sustentável. Disponível em: <http://www.mobilize.org.br/midias/pesquisas/a-caminhabilidademedida-urbana-sustentavel.pdf>. Acesso em: abr. 2018.

INSTITUTO DE POLÍTICAS DE TRANSPORTE E DESENVOLVIMENTO (ITDP). Índice de Caminhabilidade Versão 2.0 - Ferramenta. Disponível em:

<http://itdpbrasil.org.br/icam2/>. Acesso em: maio de 2018.

JACOBS, Jane. Morte e vida de grandes cidades. 1. ed. São Paulo: Martins Fontes, 2000.

SPECK, Jeff. Cidade Caminhável. 1. ed. São Paulo: Perspectiva, 2016. 272 p.

WRI BRASIL. 8 princípios da calçada. 1. ed. São Paulo. 2017. 136 p. 